NBER WORKING PAPER SERIES

\title{
ENTITLEMENT REFORMS IN EUROPE: POLICY MIXES IN THE CURRENT PENSION REFORM PROCESS
}

\author{
Axel H. Börsch-Supan \\ Working Paper 18009 \\ http://www.nber.org/papers/w18009
NATIONAL BUREAU OF ECONOMIC RESEARCH
1050 Massachusetts Avenue
Cambridge, MA 02138
April 2012

I am grateful for helpful comments by the editors, my discussant David Wise, and many conference participants. This review rests on projects with funding provided by the German Science Foundation (DFG), the State of Baden-Württemberg, the German insurance association (GDV), and the US National Institute on Aging (NIA) The views expressed herein are those of the author and do not necessarily reflect the views of the National Bureau of Economic Research.

NBER working papers are circulated for discussion and comment purposes. They have not been peerreviewed or been subject to the review by the NBER Board of Directors that accompanies official NBER publications.

(C) 2012 by Axel H. Börsch-Supan. All rights reserved. Short sections of text, not to exceed two paragraphs, may be quoted without explicit permission provided that full credit, including $\odot$ notice, is given to the source. 
Entitlement Reforms in Europe: Policy Mixes in the Current Pension Reform Process

Axel H. Börsch-Supan

NBER Working Paper No. 18009

April 2012

JEL No. H51,H55,H68

\begin{abstract}
$\underline{\text { ABSTRACT }}$
Many European countries have begun (or have announced) programs intended to reduce the growth of entitlement programs, in particular of public pensions.

Current costs are high, and the pressures will increase due to population aging and negative incentive effects. This paper focuses on the pension reform process in Europe. It links the causes for current problems to the cures required to make the pay-as-you-go entitlement programs in Continental Europe sustainable above and beyond the financial crisis. It discusses examples which appear, from a current point of view, to be the most viable and effective options to bring entitlement systems closer to fiscal balance and still achieve their key aims.

There is no single policy prescription that can solve all problems at once. Reform elements include a freeze in the contribution and tax rates, an indexation of benefits to the dependency ratio, measures to stop the current trend towards early retirement, an adaptation of the normal retirement age to increased life expectancy, and more reliance on private savings - elements of a sustainable but complex multipillar system of pensions and similar entitlement programs.
\end{abstract}

Axel H. Börsch-Supan

Munich Center for the Economics of Aging

Max Planck Institute for Social Law and Social Pol

Amalienstrasse 33

80779 Munich

GERMANY

and NBER

axel@boersch-supan.de 


\section{Entitlement Reforms in Europe:}

\section{Policy mixes in the current pension reform process}

\section{Axel H. Börsch-Supan}

\section{Introduction}

Europe is proud of its entitlement programs. They include, in approximate order of size: (a) public pensions, (b) public health care and health insurance, (c) unemployment insurance and active labor market policies, and (d) others, primarily child care, maternity benefits, family cash benefits, and means-tested social assistance, plus sickness benefits, long-term care insurance and many smaller programs. Together, these entitlement programs represent between 20 and $30 \%$ of GDP in most European countries, with considerable variation especially in Eastern Europe (Figure 1), while it is about 18.5\% of GDP in the US.

\section{Figure 1: Entitlement Programs in Europe and Other Selected Countries} (Percent of GDP, 2011)

The generosity of the European entitlement programs is considered a great social achievement because it has historically provided social stability over the life cycle and across business and political cycles. Population aging, negative incentive effects, and other design flaws, however, threaten the very core of these public support systems. As the current debt crisis in Europe shows, they may themselves become a source for fiscal instability due to their large costs.

Not only the size but also the structure of entitlements by the four above program groups is quite different across countries, see Table 1. 
Table 1: Structure of Entitlement Programs, 2011

Percent of Total Entitlement Programs

Pension expenditures account for more than half of entitlements in Italy and Greece, while they are less than 20 percent in Ireland and Denmark. Health care, in turn, accounts for the largest share of entitlements in the US and Canada with more than $40 \%$, while it is only about $22 \%$ in Estonia and Finland. The Mediterranean countries have large pensions systems, but small unemployment insurance and social assistance systems, a structure of public expenditures that has regained prominence in the current debt crisis because it worsens both long-term prospects for debt reduction (due to the implicit debt created by pensions entitlements) and the ability to sustain austerity programs (due to the lack of sufficient unemployment insurance and social assistance).

Since public pension expenditures are the single largest item in the social budget in almost all European countries, this paper largely focuses on public pension systems. They alone represent a substantial share of GDP. In 2011, Italy and France are frontrunners with some 14 percent of GDP, and in Greece, Portugal and Austria, this share is about 12 percent, roughly twice the share of GDP compared to the US (6.7 percent of GDP). In terms of fiscal stability in the current debt crisis, pension systems are a scary example how current program design, the size of future entitlements, and political credibility interact as either virtuous or vicious spirals. This paper argues that it is not a coincidence that the countries which spend the highest share of GDP in pension entitlements are also the countries which are currently most pressured to offer very high yields to sell government bonds. Through this mechanism, high pension costs imply high costs of debt service, thereby worsening the fiscal balance and crowding out other spending. 
Ironically, in spite of their size, some of the expensive pension programs nevertheless fail to provide adequate support for certain population groups since they are targeted heavily to the middle-class median voter. Greeks aged 65 and over, for example, face a poverty rate of $22.7 \%$, almost twice as large as the OECD average.

This paper links the causes for current problems to the cures required to make the typically pay-as-you-go financed entitlement programs in Continental Europe sustainable above and beyond the financial crisis. It discusses examples which appear, from a current point of view, to be the most viable and effective options to bring the entitlement system closer to fiscal balance and still achieve their key aims, e.g. preventing old-age poverty. It stresses that there is nothing like "the optimal pension reform" since the initial state (in particular the current institutional set up) varies as much as the causes for problems in the future. In any case, solutions to the demographic challenges ahead require a mix of reform elements as no single element is likely to suffice quantitatively in face of the dimensions of population aging.

The first part of the paper sets the stage with a brief overview of the current landscape of entitlement programs in Europe (Section 2).

The main body of the paper focuses on the pension reform process in Europe. Section 3 is devoted to the causes for reform, while Section 4 lines out possible cures and presents concrete examples. Specifically, Section 3 describes (a) the lack of sustainability due to population aging, (b) the negative incentive effects which threaten not only the stability of pension systems but economic growth at large, and (c) points out examples where pension adequacy fails. 
Section 4 is then devoted to the respective cures: (a) setting limits to contribution rates and increasing retirement age will lower the weight of pay-as-you-go financed public pensions; (b) private saving and longer working lives will have to fill the emerging gaps, obtaining a larger weight in retirement income; and (c) since the reform steps have large redistributive consequences, they may require additional targeting.

Section 5 provides some estimates of the fiscal effects of these reforms, and Section 6 concludes.

\section{The current design of pension systems in Europe}

Figure 1 and Table 1 have shown how different the European entitlement programs are, both in overall size (as percent of GDP) and structure (pensions vs. healthcare vs. working age vs. children).

Similarly, pension systems are very different across Europe. We focus on four dimensions which characterize the pension systems in Europe: pre-funding vs. pay-as-you-go financing; earnings-related vs. flat benefits; generosity in terms of replacement rate; and eligibility age for pension benefits. The point is not to provide an exhaustive description of European pension systems (for that purpose, see, e.g., OECD 2011) but to give an idea how diverse the initial positions are for potential pension reform in Europe.

The first characterizing dimension is the share of retirement income provided by public pay-asyou-go pension pillars vis-à-vis occupational and private pillars which are, in general, fully funded, see Figure 2. ${ }^{1}$ This dimension is important because pay-as-you-go pensions have to be

\footnotetext{
${ }^{1}$ Some occupational pensions in France are also at least partly pay-as-you-go.
} 
financed by the next generation through contributions while pre-funded pensions are financed by the same generation through savings which also enjoys the consumption value of pensions. The share of the public pay-as-you-go pillars in total retirement income varies greatly between $92 \%$ in Spain and $42 \%$ in Switzerland.

Figure 2: Public, occupational and private pension income in selected countries (Percent of total retirement income)

The second characterizing dimension is the linkage between pension benefits and contributions, which are usually a fixed percentage of earnings. Its importance stems from the underlying negative incentive effects on labor supply. It has two extremes: flat pensions without any link to earnings, usually associated with the name of Lord Beveridge, and pensions which are strictly proportional to contributions, usually associated with the name of Chancellor Bismarck. In a Beveridgian system, contributions tend to be interpreted as taxes with resulting labor supply disincentives, while in a Bismarckian system, contributions are closer to insurance premiums. $^{2}$ There are many refinements: some pension systems define pension benefits ex ante, while in others benefits emerge ex post as the outcome of life-time contributions. Often, the public pension systems consists of two parts: a flat-benefit part to prevent poverty ("pillar 0 " in the language of the World Bank: Holzmann and Hinz, 2005), and an earnings-related part which is usually capped at a maximum benefit level ("pillar 1").

Table 2 is adapted from OECD (2011) and characterizes European pension systems along these lines. The Denmark and the Netherlands, for example, have a basic pension which is essentially independent from the contributions paid and/or the income earned during working

\footnotetext{
${ }^{2}$ See Börsch-Supan and Reil-Held (2001).
} 
life (Beveridge type). France and Germany, on the other hand, have earnings-related pensions based on a point system that defines the benefits (Bismarck type). Sweden and Italy introduced "notional defined contribution systems" (NDC). These are pay-as-you-go pension systems mimicking funded systems insofar as they accrue interest on the contributions into personal accounts which are, on retirement, converted into annuities. They feature the closest link between contributions and benefits, followed by the point systems e.g. in France and Germany.

\section{Table 2: Structure of Pension Programs, 2010}

Third, pension replacement rates are a measure for the generosity (and thus costs) of pension systems. Figure 3 shows the average pension in percentage of average earnings before taxes, with a very large variation from just over $25 \%$ to almost $100 \%$. Ireland has the lowest and Greece the highest replacement rate in Europe. The OECD average is slightly above 50\%.

Figure 3: Gross relative pension level (Average pension in percent of average earnings)

Finally, the forth characterizing dimension is the eligibility (commonly: retirement) age because of its strong influence on labor supply and system costs. Figure 4 shows the statutory and effective retirement ages. Already the statutory retirement ages display an enormous variation and even more so the effective retirement ages.

\section{Figure 4: Statutory and effective retirement age}

The figures in this section show clearly how different the current pension systems in Europe are. They vary in all policy-relevant dimensions: financial mechanism, structure, generosity and labor market influence. Much of this is due to historical country-specific political and 
cultural preferences. As a first consequence, pension expenditures are only loosely related to the demographic structure of a country (see next section). Secondly, there is no single optimal design strategy for pension reform in Europe; rather, pension reform has to focus on different design dimensions in each country to account for the country-specific initial states.

\section{Causes for reform}

Population aging is one important reason to align current entitlements with future fiscal capacity. As a consequence, pension and entitlement reform is an ongoing process in virtually all European countries. It therefore may come as a surprise, how weakly the current demographic structure is linked to the current relative size of the European public pension programs.

Figure 5: Pension Expenditures (Percent of GDP, 2011) by Old-Age Dependency (Percent)

This is mainly due to the many design differences between European pension systems described in the previous section. Some of these designs are self-stabilizing and thus prevent high cost increases. This is the case, e.g., for Estonia, Poland and Sweden, and described in Section 4. Other designs create strong negative incentive effects on labor supply and generate early retirement, which decreases economic capacity and thus threatens fiscal capacity and economic growth at large. This, in turn, increases the force of population aging on pension expenditures. Figure 6 shows, while almost all European countries face increasing pension costs as percent of GDP, there are very large differences across countries. On average across the European Union, the cost share increase by $16 \%$ until 2030 and by $37 \%$ until 2050 . In 
Greece and Luxembourg, however, pension expenditures will more than double until 2050, while they are projected to decline in Estonia, Poland and Sweden.

Figure 6: Change in Pension Expenditures (Percent, 2030 and 2050 versus 2010)

The weak correlation between aging and projected pension costs, and the huge variation in cost increases are a symptom of many other reasons for reform. Subsection (a) describes the link between demography and sustainability as a reason to reform the pension systems. Subsection (b) analyses the link between expected cost increases and incentive effects that reduce labor supply. Finally, subsection (c) is concerned with the redistributive features of European pension systems and the alleviation of old-age poverty.

\section{(a) Population aging and lack of sustainability}

While all European countries are aging, there are remarkable differences. Italy, Austria and Germany will experience a particular dramatic change in the age structure of the population. Such change is much less incisive in France, Great Britain, and Scandinavia. The severity of the demographic transition in most of Europe has two causes: a quicker increase in life expectancy than elsewhere, partly due to a relatively low level until the 1970s, and a more incisive baby boom/baby bust transition (e.g., relative to the United States) to a very low fertility rate in some countries (1.2 children per lifetime in Italy, Spain and Greece, 1.3 in Austria and Germany).

Both demographic developments have a similar consequence: the ratio of elderly to working age persons - the old age dependency ratio - will increase steeply, see Figure 7. According to the latest projections of the European Union, the share of elderly (aged 65 and above) will 
exceed a quarter of the population in 2030. The old age dependency ratio will more than double during the next 50 years. In Italy, Spain, Austria and Germany, there will be one person aged 65 and over for every two other persons. Moreover, population aging is not a transitory phenomenon but will persists even after the baby boom generation will be deceased: the dependency ratio plateaus after 2040 for most European countries and will not return to preaging levels for the foreseeable future.

\section{Figure 7: The Old-Age Dependency Ratio in Europe and Selected Countries (Population 65+/population 20-64: 2010-2050)}

While both demographic developments, decreasing fertility and increasing longevity, have similar consequences, it is important to distinguish the two causes because they imply different policy responses which is often confused in the public debate. We take Germany as an example, but similar features exist in its neighboring countries Austria, the Netherlands, and Switzerland, see Figure 8 . The sharpness of the change is generated by the first cause, the sudden decline in birth rates during the baby boom to baby bust transition in the 1970s. The number of children born during the baby boom in the 1960 s was about 2.4 children per woman and led to the bulge in the age pyramids of Figure 8. In 1997, these children were about 35 years old. The baby bust started with a sudden decline to 1.3 children per woman, visible in the much smaller number of persons aged below 35. 30 years from now, the numerous baby boomers will be pensioners, and the much smaller baby bust generation will have to finance them. Compensating this by changes in the retirement age is virtually impossible and other policy responses are needed, see below. 
Figure 8: Baby Boom to Baby Bust Transition in Europe

The second cause for the demographic transition is the secular change in life expectancy. This is a more steady development, and it is likely to persist after 2035. Figure 9 shows that since 1970, the remaining life expectancy of German men and women at age 65 has increased by 4 years. It is projected to increase another 3 years until 2030. This implies that a pension in 2030 will be paid 7 more years than in 1970. Since the average length of pension receipt was about 15 years in 1970, the increase in life expectancy represents an expansion of pension benefits by almost 50 percent. As shown below, an increase in the actual retirement age is a feasible and effective cure for this cause of financial strain.

\section{Figure 8: Life Expectancy at Age 65, German Men and Women, 1970-2040}

Public health insurance (and in particular long-term care insurance, LTC) face similar sustainability problems because they are financed pay-as-you-go by the younger generation and give the bulk of benefits (all in LTC) to the older generation.

\section{(b) Design flaws and negative incentive effects}

The well-known demographically induced problems are not the only challenges for the European entitlement programs. Another challenge are the distortions created through financing mechanisms and design flaws.

Some entitlement programs may be considered a fair insurance because the expected benefits of the program equals the expected contributions over the life-course. Therefore, at least according to traditional economics, one would not expect very large labor supply disincentive 
effects. ${ }^{3}$ Examples are most defined contribution pensions (including NDC systems) and most private health insurance. Most programs, however, have strong transfer components, see Section 2, e.g. payroll-tax financed pension programs with flat benefits (in Great Britain, Netherlands, Switzerland). Such payroll taxes are known to distort labor supply of the younger generation (Blundell et al. 1998). Since contributions to social insurance are a large part of total labor compensation, see Figure 10, and increase total labor costs, demand for labor declines, with consequent higher unemployment and lower economic growth. Reducing the contribution burden is therefore not only important for the long-run stability and sustainability of the pension system itself, but for fiscal stability and economic performance at large. It is important to keep both in mind, since economic growth is an important source to finance future pensions.

\section{Figure 10: Composition of total hourly labor compensation in Europe (percent, Eurostat)}

There are two additional tax components in pension contributions. Since the implicit return from a mandatory pay-as-you-go system tends to be lower than the explicit return on the voluntary investment in a funded pension, there is an implicit tax in all pay-as-you-go systems, see Börsch-Supan and Reil-Held (2001). Moreover, most public pension systems are not actuarially neutral because they distort labor supply of the older generation through early retirement incentives. This creates an implicit tax on working longer, measured e.g. by the Gruber-Wise group and the OECD. ${ }^{4}$ Figure 11 links an index of this implicit tax to the share of those men who are already retired at age 60-64. In countries with a large implicit tax on

\footnotetext{
${ }^{3}$ See the implicit tax argument in pay-as-you-go systems below.
} 
working longer (e.g. Belgium, France, Italy, and the Netherlands), the share of retirees is much larger than in countries with a low implicit tax (e.g. Sweden, the US and Japan).

\section{Figure 11: Tax force and early retirement}

The aggregate correlation in Figure 11 permits no causal interpretation. Supplemental analyses, however, have produced convincing evidence for causality. First, Figure 12 shows that especially in Belgium, France, the Netherlands, and Italy, very few workers aged 60-64 are still in the labor force. This is quite different from what it was in the 1960s, in spite of a lower life expectancy and a higher prevalence of illness at that time.

\section{Figure 12: Labor force participation among men aged 60-64, 1960-2008} (percent of male population 60 to 64 )

Second, this decline is not a "natural trend" tied to secular income growth. It did not occur, for example, in Japan and Sweden. Rather, the decline happened exactly when the tax force on working longer increased; the decline has been largely "engineered" by the incentive effects that are intrinsic in some of the public pension systems, in particular by an incomplete adjustment of benefits to retirement age. A particularly striking historical example for the exogenous policy change that can be exploited for formal microeconometric evidence with a causal interpretation is the German pension reform in 1972 , see Figure $13 .^{5}$

\footnotetext{
${ }^{4}$ Gruber and Wise (1999), Blondal and Scarpetta (1998).

${ }^{5}$ Cf. Börsch-Supan and Schnabel (1999), Börsch-Supan (2000), Gruber and Wise (2003).
} 
The German public pension system with its "flexible retirement" introduced in 1972 tilted the retirement decision heavily towards the earliest retirement age applicable because the annual benefit was essentially independent of the retirement age. Hence, retiring earlier gave a worker essentially the same pension for a longer time. At the then prevailing generous replacement rates, this was a pretty good deal. The 1992 reform, in force after 1997, has diminished this incentive effect, but pension benefits are still not actuarially neutral at conventional interest rates.

\section{Figure 13: Average Retirement Age in Germany, 1960-2008}

The retirement behavior of entrants into the German public retirement insurance system reflects these incentive effects quite clearly in Figure 13. Immediately after the introduction of "flexible retirement" in 1972, the average retirement age declined dramatically by more than 3 years. We interpret this as a clear sign of a policy reaction. The most popular retirement age switched by 5 years from age 65 to age 60 . As a striking example of effective reform, a large part of this decline has been reversed since 1997.

\section{(c) Lack of adequacy and perverse redistribution}

Many countries have a minimum pension, either as statutory basic or minimum pension or effective through social assistance mechanisms. ${ }^{6}$ As Figure 14 shows, this has kept poverty rates low in most European countries, at least relative to the OECD average and certainly vis-àvis the United States. 
Figure 14: Old-Age Poverty Rates, 2010

(OECD, 2008)

There are, however, three striking exceptions where the old-age poverty rate exceeds $20 \%$ of individuals aged 65 and more: Greece, Spain, and Ireland. Ireland spends very little on pensions as we have seen in Table 1. Greece and Spain, however, have both above average pension replacement rates (see Figure 3) but nevertheless very high old-age poverty rates. While in most countries, pension systems and/or their associated social assistance systems distribute from rich to poor, this suggests some extent of perverse redistribution in Greece and Spain.

\section{Curing the problems}

Reform processes are under way in almost all European countries. Some countries reformed early in the 1980 s, e.g. Sweden, most countries much later, some not at all, e.g. Greece. Typically, we have experienced "reforms in installments". These reforms have combined "parametric" elements (introducing actuarial adjustments, changing the benefits indexation formula, increasing the retirement age) with "fundamental" elements (changing the financial mechanism by moving substantial parts of retirement income from public pensions to private savings). Table 3 presents a synopsis.

\section{Table 3: Synopsis of pension reform elements in Europe, 1980-2010}

\footnotetext{
${ }^{6}$ E.g. in Germany: the tax-financed "Grundsicherung im Alter" which is not part of the German public pension system.
} 
The multitude of reform elements in Europe is partly a result of initially different and different political preferences. It also reflects the fact that there is no single reform measure that can lead to a stable and sustainable system of old-age provision; rather, a mix of several reform elements is needed. If the goal is to restore fiscal sustainability, then reform will require an overhaul of the existing pay-as-you-go systems as well as the re-introduction of private saving as a major source of future retirement income. Extreme policies are unlikely to work: neither can the public pension systems alone provide a sufficient retirement income at reasonable tax and contribution rates, nor can private savings fully substitute for pay-as-you-go pensions.

Relying on public pay-as-you-go financed pensions alone is not possible because the resulting tax and contribution rates from maintaining the current generosity (and thus costs, see Figure 6) will damage economic growth through the negative labor supply incentive effects described earlier. Further increases of the tax and contribution rates are particularly damaging in those EU countries that already have high total labor costs, in particular Germany, Austria, Denmark and Sweden, see Figure 10.

In turn, transiting pensions entirely to private saving is also not a policy option. One fatal reason against such an option is simply that it is too late. Saving requires time, and there will not be sufficient time until 2030 for the baby boomers to accumulate funds in the order of magnitude required to finance a full pension. Time and history is of the essence in pension reform. The baby boom/baby bust transition dictates the time schedule and makes reforms impossible which were possible 25 years ago - such as a complete transition to a fully funded system. 
There are other reasons to advocate a more subtle but also more complex multipillar system rather than a pure pay-as-you-go or a pure fully funded system. An important reason is diversification. Pay-as-you-go systems carry large demographic and political risks, while fully funded systems carry large capital market risks. Since these risks are not perfectly correlated, diversification provides lower risk of poor outcomes than monolithity.

Hence, in order to achieve long-run fiscal balance, reforms typically need to include two components: adapting the public system to demographic change under the restriction that taxes and contributions cannot increase much further, and strengthening private savings under the restriction that not much time is left until 2035. This first subsection addresses the first, subsection (b) the second element. Subsection (c) discusses issues of targeting and poverty alleviation.

\section{(a) Adapting pay-as-you-go public pension systems}

Stabilizing tax and contribution rates implies expenditure cuts if and when at the same time demographic change reduces the number of contributors to, and increases the number of beneficiaries from, the pay-as-you-go pension systems. Pension expenditures have two dimensions: the level of benefits (via the replacement rate) and the duration of benefits (via the retirement age). Expenditure cuts are easier to shoulder if they involve both dimensions.

Both dimensions are politically difficult. Fortunately, the demographic change, while dramatic, is of a magnitude that is far from absorbing all available resources. Figure 15 shows a rough approximation of the force of aging on economic growth, represented by the loss of productive capacity due to a decline of the number of workers relative to the number of consumers. It is measured as the percentage change of the old-age dependency ratio (from Figure 7). The 
dependency ratio deteriorates at a rate of about $0.2-0.5$ percent p.a., with a large variation in timing across the selected countries. This is much less than the long-run averages of productivity growth which is about 1.5 to 2.5 percent p.a. for most European countries. Hence, population aging absorbs between a seventh and a third of future productivity growth leaving the bulk for real income growth. Pension benefits can therefore rise in real terms in spite of population aging, and all what is required is a growth rate of benefits that remains below the growth rate of wages.

\section{Figure 15: The force of aging in terms of the rate of economic growth}

\section{(a.1) Adapting the level of benefits: reducing the replacement rate}

How much benefit increases have to be dampened depends on the speed and the extent of demographic change in each country relative to its productivity growth. France and Sweden, for example, will need less adaptation than Italy and Germany. Some countries have formalized this link between demographics and benefit level. Sweden and Italy have introduced notional defined contribution (NDC) systems which compute benefits on the basis of the accumulated contributions plus some fictitious interest which depends on demographic essentials such as life expectancy and dependency ratio and wage growth. In macroeconomic abstraction, this interest rate should be the labor force growth rate plus productivity growth. Since the labor force growth rate is declining as a population ages, a NDC system features a declining replacement rate in the course of population aging. Moreover, longevity decreases the value of the annuity emanating from the accumulated notional wealth. 
Germany has taken an apparently very different approach, preserving the defined benefit structure that has so much political acceptance in many countries. It augmented the conventional benefit indexation formula which increases benefits at the rate of wage (in other countries: price) increases by a new factor, the so-called "sustainability factor". ${ }^{7}$ This factor reflects the development of the relative number of contributors to pensioners, the system dependency ratio, which is the most important long-term determinant of pension financing. The annual benefit changes are then proportional to two factors: changes in gross earnings minus contributions to the pension system (positively related), and changes in the system dependency ratio (inversely related), weighted harmonically: ${ }^{8}$

$$
P V_{t}=P V_{t-1} \cdot\left(\frac{A G E_{t}}{A G E_{t-1}} \frac{\left(1-\tau_{t}\right)}{\left(1-\tau_{t-1}\right)}\right)^{a} \cdot\left(\frac{S D R_{t-1}}{S D R_{t}}\right)^{1-a}
$$

where PV: pension value per earnings point

AGE: average gross earnings

$\tau$ : contribution rate to public and private pensions

SDR: system dependency ratio: pensioners/contributors

The weight has been set achieve a politically determined contribution rate target. Thise new pension formula will lead to decreases in pension benefit levels vis-à-vis the path of wages. Currently, gross benefits are about 48 percent of gross earnings. This corresponds to a net pension level of about 70 percent of net earnings. In 2035, when the plafond of population aging is reached, the gross pension level will be about 40 percent.

The Swedish and the German reform approaches look very different. However, as BörschSupan and Wilke (2005) point out, the sustainability factor can almost perfectly mimic a

\footnotetext{
${ }^{7}$ Börsch-Supan, Reil-Held und Wilke (2003), Börsch-Supan (2004).

${ }^{8}$ The actual formula avoids exponentiation and features various lags due to data availability.
} 
national defined contribution system; it can thus be interpreted as a notional defined contribution system "wrapped" as a defined benefit system. The different "selling approaches" responded to the political economy differences between Sweden and Germany.

(a.2) Adapting the duration of benefits: increasing the retirement age

The other crucial dimension of pension expenditures is the duration of pension benefits, determined by the difference between the age at which pension benefits are taken up and life expectancy. As pointed out earlier, life expectancy is projected to increase by about 3 years between now and 2030. This increase is expected to be about the same for all European countries. Figure 4 has shown the international differences in both normal retirement age (the statutory age to take up old-age pensions) and actual retirement age (the age in which workers leave the labor force) which is in most European countries equal to the age in which some kind of public pension is taken up. The two main policy instruments to reduce the duration of benefits are increasing the statutory retirement age and reducing early retirement benefits. Both instruments are extremely unpopular throughout Europe.

In Germany, the 1992 reform has succeeded in abolishing most early retirement pathways without actuarial adjustments. This law became effective in 1997, but it has a transition period until 2017, see Figure 16.

\section{Figure 16: Projected Retirement Age, Germany, 1997-2035}

In addition, Denmark, Germany, France and the UK have enacted increases of the statutory normal retirement age (e.g. Denmark and Germany from 65 to 67 years, UK even to 68 years, while in France only from 60 to 62 years). Most increases are slow and gradual. In Germany, it 
has started in 2011 with monthly steps such that the retirement age of 67 will be reached in 2029. This increase corresponds to two-thirds of the projected change in life expectancy. This approximately keeps the ratio of time spent in working life to time spent in retirement constant and thus neutralizes, from an expenditure point of view, the effect of longevity increases on pension expenditures.

In some countries, the statutory retirement age is not the primary determinant of actual retirement age but the number of years worked. In Germany, 45 years of contributions will generate a full pension even if these service years are reached before age 65 . In some countries, the number of required contribution years is much lower, notably in France, Greece and Italy, and vary by profession, see the quite colorful Greek case described by Börsch-Supan and Tinios (2002). With increasing life expectancy, such mechanisms create a very long and thus costly duration of pension benefit recipiency. If one follows the above logic, the required number of service years should also be adapted to the longer life span. This has been particularly controversial in France and Italy

\section{(b) Private saving and pre-funding}

Reducing the first pillar of pay-as-you-go financed public pensions creates a gap in retirement income relative to what workers have become accustomed to. There are only two mechanisms to fill the gap: working longer and saving more. ${ }^{9}$ A reasonable approach is of course to exploit both mechanisms, in spite of the unpopularity particularly of the first mechanism described in the preceding subsection.

\footnotetext{
${ }^{9}$ Higher fertility is only a long-run solution and does not help to offset the fiscal strains generated by the babyboom generation. Higher migration would help but net immigration numbers need to be unrealistically large to offset the domestic aging process, see United Nations Population Division (2001).
} 
Figure 17 shows how this can work, again using the recent German reform proposals as an example. Taking account of the increase in the normal retirement age to 67 , which increases pension benefits according to the German benefit formula, and adding income from private retirement savings, the reform proposal manages to deliver an income level for retirees that is comparable to today's income level, in spite of the reduction of public pillar pensions according to the sustainability formula. This projection assumes a private retirement saving rate of $4 \%$ of gross income from 2009 on. These 4\% are the current limit of tax-subsidization, if either occupational pensions ("second pillar") or private savings ("third pillar") are used to finance additional retirement income. Under many circumstances, both subsidies can be combined such that $8 \%$ of gross income can be tax-privileged.

\section{Figure 17: Projected Retirement Income Components, Germany, 2002-2040}

This is important for the early baby boomers. Figure 17 shows the crux of all transition schemes to more funded pensions via private saving: the transition generation will have to pay extra in order to maintain their total retirement income when the income from pay-as-you-go pensions is reduced. For the younger generation, born after about 1980 and retiring after about $2040,4 \%$ is sufficient to maintain or even to obtain higher retirement income levels than today, but a saving rate of $8 \%$ is required for the cohort with the highest transition burden, the early baby boomers born in the 1950s and early 1960s.

Such high saving rates are feasible, but they of course hurt consumption. They are the price for reforming too late. Figure 2 has shown the weight of the three pillars in selected European countries. Those countries, which have reformed their pension systems in the $1980 \mathrm{~s}$ by transiting to multipillar systems (Switzerland, the Netherlands, Great Britain), have succeeded 
in lower contribution rates; they also need lower private saving rates because they have saved for a longer time, accumulating more capital and enjoying higher compound interest. The latecomers in this process (Spain, Germany, France and Italy) still have dominant first pillars and need to save much more and much quicker, if they want to alleviate the tax and contribution burden and at the same time maintain their accustomed retirement income levels. Given the short time period until the baby boomers retire, this may only be an option for later generations but not feasible for them.

\section{(c) Targeting and redistribution}

Cutting pay-as-you-go pensions to a sustainable share of GDP will particularly hurt those who have earned very little and whose saving capacity is also low. The reform-driven reduction of replacement rates will drive workers who have earned incomes only slightly above the poverty line into old-age poverty after retirement.

This dilemma between sustainability and old-age poverty can only be solved by targeting policies for those who are in danger of old-age poverty. One instrument are basic and/or minimum pensions, see Table 2. Another instrument is a non-linear (concave from above) schedule linking benefits to contributions (e.g. via the PIA/AIME conversion in the US Social Security system).

Some countries have basic or minimum pensions which prevent old-age poverty virtually by definition, as they set the minimum level of pension income just above the poverty level (e.g. Denmark and Germany). In other countries, such basic or minimum pensions are not existent or provide income below the poverty line (e.g. Greece and Ireland). Such countries need to redistribute more from rich to poor pensioners if they want to prevent old-age poverty. 


\section{Implications for fiscal stability}

Since pensions are a large part of entitlements which in turn take up a large share of public expenditures, fiscal stability is closely linked to the path of future pension expenditures. The Economic Policy Committee of the EU, together with the OECD, provide projections on future public pension expenditures, see Figure 18.

\section{Figure 18: Projected Public Pension Expenditures (\% GDP), 2007-2050}

Two countries stand out: Italy, because it has currently the highest public pension expenditures, and Greece, because it features the most dramatic increase. While both countries have very high pension expenditures today, their dynamics could not be more different: expenditures in Italy are stable until 2030, rise only weakly until 2040 and then decline, while they rise in proportion to the dependency rate in Greece.

The reason for this tale of two countries is quickly told. As Section 2 described, Greece has a defined benefit system with a high replacement rate and very early retirement. So far, there is no feedback of demography to this generosity. Italy features two pension systems. The old system is similar to the current Greek system, while the new system is modeled after the Swedish NDC system. Workers who started after 1993 are completely in the new NDC system, while those who had more than 18 years contribution before 1996 are completely in the old system. Those in between are under a "pro rata" system: benefits corresponding to contributions before 1993 are paid according to the old system and the ones after 1993 according to the NDC. ${ }^{10}$ Hence, the Italian system has not yet deeply cut benefits. The new

\footnotetext{
${ }^{10}$ I am grateful to Agar Brugiavini for this description.
} 
system, however, has a strongly stabilizing influence on pension expenditures, see Section 4, if it is actually implemented. Some crucial parameters, such as the fictitious interest rate of the NDC system and the conversion factor of the notional wealth into the pension annuity, however, are politically much more vulnerable in the Italian copy than in the Swedish original; the pension costs expected by financial markets may thus be higher than suggested by Figure 18. It is therefore no coincidence that Greece and Italy are currently most under pressure from financial markets.

In order to understand how the projections in Figure 18 depend on demographic trends and future policy actions, it is helpful to decompose the projected expenditure increases into four potential causes (old-age dependency, employment rate, take-up ratio, and benefit ratio) according to the following equation, see Carone et al. (2008):

$$
\frac{\text { PensExp }}{G D P}=\frac{\text { Pop }>65}{\text { Pop }(15-64)} \times \frac{\text { Pop }(15-64)}{\text { EmplNo }} \times \frac{\text { PensNo }}{\text { Pop }>65} \times \frac{\text { PensExp } / \text { PensNo }}{\text { GDP / EmplNo }}
$$

Results are displayed in Table 4:

Table 4: Decomposition of Projected Changes in Pension Expenditure, 2005-2050 (gross public pension expenditures as percent of GDP)

The demographic pressure, measured as the dependency ratio effect, is positive in all countries, especially the Mediterranean countries. Some countries have strong counterbalancing forces, e.g. Sweden and Italy. This is the effect of the automatic stabilizers in the NDC systems, somewhat weaker in Germany with its sustainability factor and the gradual increase of its retirement age. These mechanisms reduce the benefit and take-up ratios and increase the employment, mainly through later retirement. In other countries, such as Spain (Greece did not provide figures for this EU exercise), demographic factors were not or only very little 
dampened by countervailing policy measures. Table 4 shows that the demographic pressures can effectively be counteracted by the policy mixes described in Section 4 .

Moog, Müller and Raffelhüschen (2010) have provided estimates of the "implicit pension debt" and its reduction through pension reform. He computes the present discounted value of future pension entitlements and subtracts the present discounted value of future contributions. In virtually all countries, entitlements exceed contributions in present discounted value, leaving an implicit debt. Figure 19 shows the effect of selected recent reforms on this implicit pension debt, expressed as percent of GDP. While these figures rest on many assumptions and are very sensitive to the choice of a discount rate, the overall message is robust: the implicit pension debt exceeds the explicit government debt in most European countries by several multiples. Pension reform has improved this fiscal imbalance dramatically in some countries (e.g., France and Austria), and significantly in others (e.g., Germany). There is, however, little change in the US and even an increase in the UK.

\section{Figure 19: Projected implicit pension debt before and after recent reforms (\% GDP)}

Werding (2007) provides a similar calculation for the effects of the various German reform steps, see Figure 20.

\section{Figure 20: Projected implicit pension debt before and after recent reforms (\% GDP)}

The gap between unfunded pension liabilities and future contributions corresponds to the implicit pension debt of Figure 19. His estimate of the reform effects are larger. The 1992, 2001 and 2004 acts reduced the benefit ratio in several steps, while the last reform step increased the statutory eligibility age from 65 to 67 . The largest effect was the change from 
gross to net wage indexation in 1992, and the introduction of the sustainability factor in 2004 . Figure 20 re-iterates our earlier message: the fiscal pressure of entitlement programs can and have been reduced substantially by relatively mild parametric reforms.

An indicator of long-term fiscal balance which is less sensitive to assumptions about the discount rate and thus timing of events is the sustainability gap. It departs from a projection of pension expenditures, a projection of pension contributions, and a final level of debt (e.g., the $60 \%$ of GDP defined in the Maastricht treaty) to be achieved after a target date. The sustainability gap then measures the additional income (primary balance as percent of GDP) necessary to avoid ending up with a higher final level of debt at the target date. In Figure 21, based on the latest report by the European Commission, S1 takes the year 2060 as the target date, while S2 assumes an infinite horizon.

\section{Figure 21: Sustainability gap in Europe (\% GDP)}

The Commission report shows that only Denmark features a fiscally sustainable pension system according to these calculations; closely followed by Finland and Sweden, plus Bulgaria and Estonia. In all other European countries, achieving fiscal sustainability requires further reforms. Figure 21 shows the particularly precarious situation of Greece, but also the unsustainability of the pension systems in Ireland and the UK. The results by the Commissions depicted in Figure 21 only partly include the costs of the financial crisis. Since the calculations were made, the debt taken on through stimulus and bank rescue packages have worsened the debt situation considerably. 


\section{Conclusions}

The major European pension systems (France, Germany, Italy, Spain) still have some ways to go in order to become financially sustainable. This paper has shown that this goal is achievable with a combination of reasonable policy steps. Italy, for example, has introduced a new entrants system that will stabilize pension expenditures if it is implemented consistently also in the future. Sweden with its NDC system has no sustainability gap. Germany has substantially reduced its implicit pension debt through a set of politically accepted gradual steps: increasing retirement age, indexing benefits to the system dependency ratio, and introducing individualaccounts-type private pensions to fill the emerging pension gap.

The recent crisis makes pension reform even more urgent. It is no coincidence that Greece and Italy are currently most under pressure. These countries have the highest pension expenditures as share of GDP in Europe. In Italy, these high pension expenditures are at least stable; but they will remain a fiscal challenge as they will not get lower for the foreseeable future and its parameters face political risks. Pension expenditures are still dramatically increasing in Greece. Without pension reform which cuts the high share of pension expenditures in GDP, no fiscal consolidation appears possible.

There is no single "optimal pension policy" since the initial state (general welfare state design emerged through culture, history, and political preferences) and problems (pressure through demography, design flaws) differ so much among countries. Rather, the policy mix between reducing pay-as-you-go benefit levels, increasing retirement age, introducing actuarial adjustments, and establishing occupational and individual funded pensions has to be different across countries. 
Moreover, restrictions differ across countries. Building up funded pensions takes time. The feasibility of a transition strategy depends on the time left until the "baby-boom bulge" will enter retirement. This differs across countries. Moreover, it depends on the current size of the pay-as-you-go pillars. The higher the pay-as-you-go share is currently, the harder is a transition during the remaining years.

What has been emerged as the most effective reform? The introduction of NDC systems have reduced fiscal strain when it was done early and consistently, like in Sweden. In Italy, not only is the demographic pressure much higher, but the introduction was also effectively postponed until after the baby boom generation will have retired, and there are many loopholes in the actual implementation, e.g. in the definition of the conversion rate to an annuity which leave room for political maneuvering. The "dressing" of the reform as a new NDC system did help in the political economy situation in Sweden, to some extent also in Italy. It failed, however, in Germany, where the taste of a funded system seems unpalatable. "Dressing" a similar reform in terms of a complex defined benefit formula was politically much easier.

Automatic stabilizers, such as the NDC systems in Sweden, Italy and Poland, and the indexation of pension benefits to the system dependency ratio in Germany, may help to put pension systems on a long-run fiscally sustainable path since they are sheltered from day-today political opportunism. One may want to introduce similar automatic rules for the retirement age, such as a proportionality rule which keeps the ratio of time spent in retirement to time spent working constant. The sheltering effect, of course, goes only so far. In Germany, for example, the sustainability factor in the benefit formula has been set out of force through a "pension benefit guarantee" which rules out any nominal benefit reduction, and parts of the dynamic increase in the retirement age has been offset by the introduction of new duration-of- 
service-rules. By and large, however, pension reforms introducing automatic stabilizers have been more successful in achieving long-term fiscal balance than those without such mechanisms. 


\section{References}

Balassone, Fabrizio, Jorge Cunha, Geert Langenus, Bernhard Manzke, Jeanne Pavot, Doris Prammer and Pietro Tommasino (2009): Fiscal sustainability and policy implications for the euro area, European Central Bank, WORKING PAPER SERIES NO 994 / JANUARY 2009

Berkel, B., and Börsch-Supan, A. (2004): Pension Reform in Germany: The Impact on Retirement Decisions. Finanzarchiv, Vol 60, No. 3, 393-421.

Blanchard, O.J. (1990), „Suggestions for a New Set of Fiscal Indicators“, OECD Economics Department Working Paper No 79.

Blanchard O.J., J.C. Chouraqui, R.P. Hagemann und N. Sartor (1990), „The Sustainability of Fiscal Policy: New Answers to an Old Question“, OECD Economic Studies 15: 7-36.

Blondal, S., and S. Scarpetta (1998): The retirement decision in OECD countries, Working papers (Organisation for Economic Co-operation and Development. Economics Dept.); no. 202

Blundell, R., A. Duncan and C. Meghir (1998): Estimating Labor Supply Responses Using Tax Reforms, Econometrica 66(4), 827-862.

Börsch-Supan, A. und R. Schnabel, 1998, Social Security and Declining Labor-Force Participation in Germany. American Economic Review 88, 173-178.

Börsch-Supan, A., 2000, Incentive Effects of Social Security on Labor Force Participation: Evidence in Germany and Across Europe. Journal of Public Economics, Vol. 78, 25-49. 
Börsch-Supan, A., und M. Miegel (Eds.), 2001, Pension Reform in Six Countries, Springer. Heidelberg, New York, Tokyo.

Börsch-Supan, A. und A. Reil-Held (2001): How much is Transfer and how much Insurance in a Pay-As-You-Go System? The German Case, Scandinavian Journal of Economics, Vol. 130, No.3, 505-524.

Börsch-Supan, A. und P. Tinios (2002): The Greek Pension System: Strategic Framework for Reform, In: R. C. Bryant, N. C. Garganas, G. S. Tavlas (Eds.), Greece’s Economic Performance and Prospects, Bank of Greece, 361-451.

Börsch-Supan, A., (2005): Suomen vuoden 2005 eläkeuudistus, Kansantaloudellinen aikakauskirja, The Finnish Economic Journal, Vol. 1/2005, 101.vsk, 52-71.

Börsch-Supan, A. und C. B. Wilke (2005): The German Public Pension System: How it will become an NDC System Look-Alike, In: Robert Holzmann and Edward Palmer (Eds.), Pension Reform - Issues and Prospects for Non-Financial Defined Contribution (NDC) Schemes, World Bank, Washington D.C., 573-610.

Börsch-Supan, A., 2007, Rational Pension Reform, Geneva Papers on Risk and Insurance: Issues and Practice, Nr. 4, 430-446.

Börsch-Supan, A., Bucher-Koenen, T., Reil-Held, A. und C. Wilke (2008): Zum künftigen Stellenwert der ersten Säule im Gesamtsystem der Alterssicherung, DRV-Schriften, Band 80, 13-31. 
Börsch-Supan, A. und R. Schnabel (2010): Early Retirement and Employment of the Young in Germany, In: Gruber, J. and D. A. Wise (Eds.), Social Security Programs and Retirement around the World, University of Chicago Press, Chicago, 147-166.

Carone, Giuseppe, Declan Costello, Nuria Diez Guardia, Per Eckefeldt and Gilles Mourre (2008): Economic Growth and Fiscal Sustainability in the EU: The Impact of an Ageing Population, in: Daniele Franco (ed.), Fiscal Sustainability: Analytical Developments and Emerging Policy Issues, Banca d'Italia: Rome.

Dang, Thai-Thanh, Pablo Antolin, Howard Oxley (2001): Fiscal Implication of Ageing: Projections of Age-related Spending, Organisation for Economic Co-operation and Development (OECD) Working Paper No. 305

Economic Policy Committee (2003): „The Impact of Ageing Populations on Public Finances: Overview of Analysis Carried out at an EU Level and Proposals for a Future Work Programme“, Doc. No. EPC/ECFIN/435/03-EN final.

European Commission (2005): „The 2005 projections of age-related expenditure (2004-2050) for the EU-25 Member States: underlying assumptions and projection methodologies“, European Economy, Special Report No. 4/2005.

European Commission (2009): „Sustainability Report - 2009“, European Economy No. 9/2009.

European Commission (2010): „Public Finances in EMU - 2010“, European Economy No. $4 / 2010$. 
European Commission (2010): Joint Report by the Economic Policy Committee (Ageing Working Group), the Social Protection Committee (Indicators Sub-Group) and the Commission services (DG for Economic and Financial Affairs and DG Employment, Social Affairs and Equal Opportunities) on Pensions: Progress and key challenges in the delivery of adequate and sustainable pensions in Europe, EUROPEAN ECONOMY Occasional Papers 71

Gruber, J. und Wise, D. A. (eds., 1999), Social Security and Retirement Around the World. Chicago, London: University of Chicago Press.

Gruber, J., and D. A. Wise (eds., 2003), Incentive Effects of Public Pension Systems, University of Chicago Press, Chicago, 285-344.

Gruber, J. and D. A. Wise (eds., 2010), Social Security Programs and Retirement around the World, University of Chicago Press, Chicago.

Holzmann, Robert, and Richard Hinz (2005): Old-Age Income Support in the 21st Century: The World Bank's Perspective on Pension Systems and Reform, The World Bank: Washington, DC.

Moog, Stefan, Christoph Müller, and Bernd Raffelhüschen (2010), Ehrbare Staaten? Die deutsche Generationenbilanz im internationalen Vergleich: Wie gut ist Deutschland auf die demografische Herausforderung vorbereitet? Diskussionspapier Forschungszentrum Generationenverträge, Albert-Ludwigs-Universität Freiburg

OECD Social Expenditure database (SOCX, www.oecd.org/els/social/expenditure, Nov. 2011)

OECD (2011), Pensions at a Glance, OECD, Paris. 
United Nations Population Division (2001): Replacement Migration: Is It a Solution to Declining and Ageing Populations? New York: United Nations.

Werding, M. (2007): „Implicit Pension Debt and Fiscal Sustainability: An Assessment for Germany“،, in: Morten Balling, Ernest Gnan und Frank Lierman (Hrsg.), Money, Finance and Demography: The Consequences of Ageing, SUERF: Vienna, S. 147-174.

Werding, M. und H. Hofmann (2008): Projektionen zur langfristigen Tragfähigkeit der öffentlichen Finanzen, ifo Beiträge zur Wirtschaftsforschung, Bd. 30, ifo Institut: München. 


\section{Figure 1: Entitlement Programs in Europe and Other Selected Countries}

\section{(Percent of GDP, 2011)}

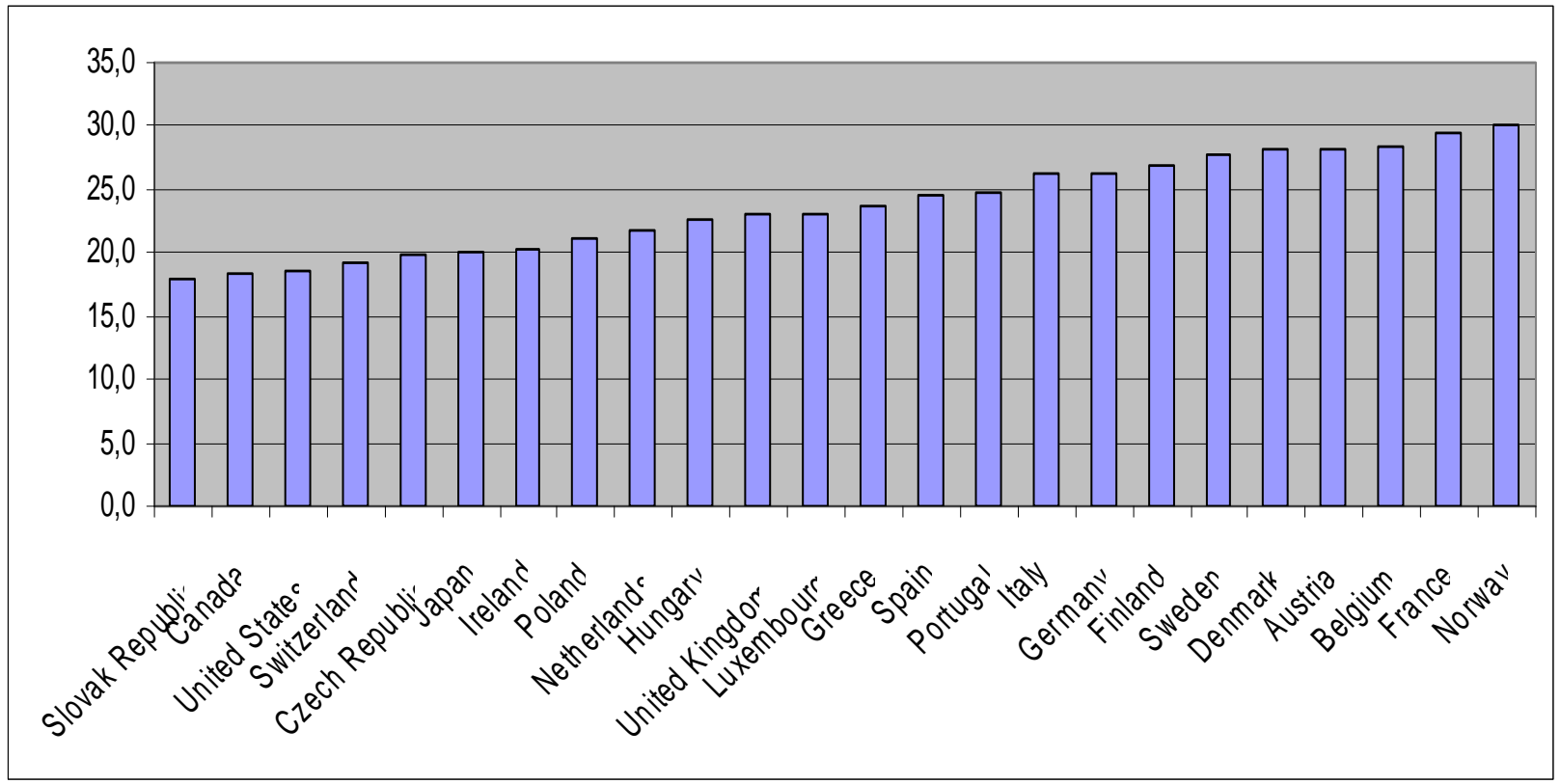

Source: OECD Social Expenditure database (SOCX, www.oecd.org/els/social/expenditure, November 2011). 
Figure 2: Public, occupational and private pension income in selected countries

(Percent of total retirement income)

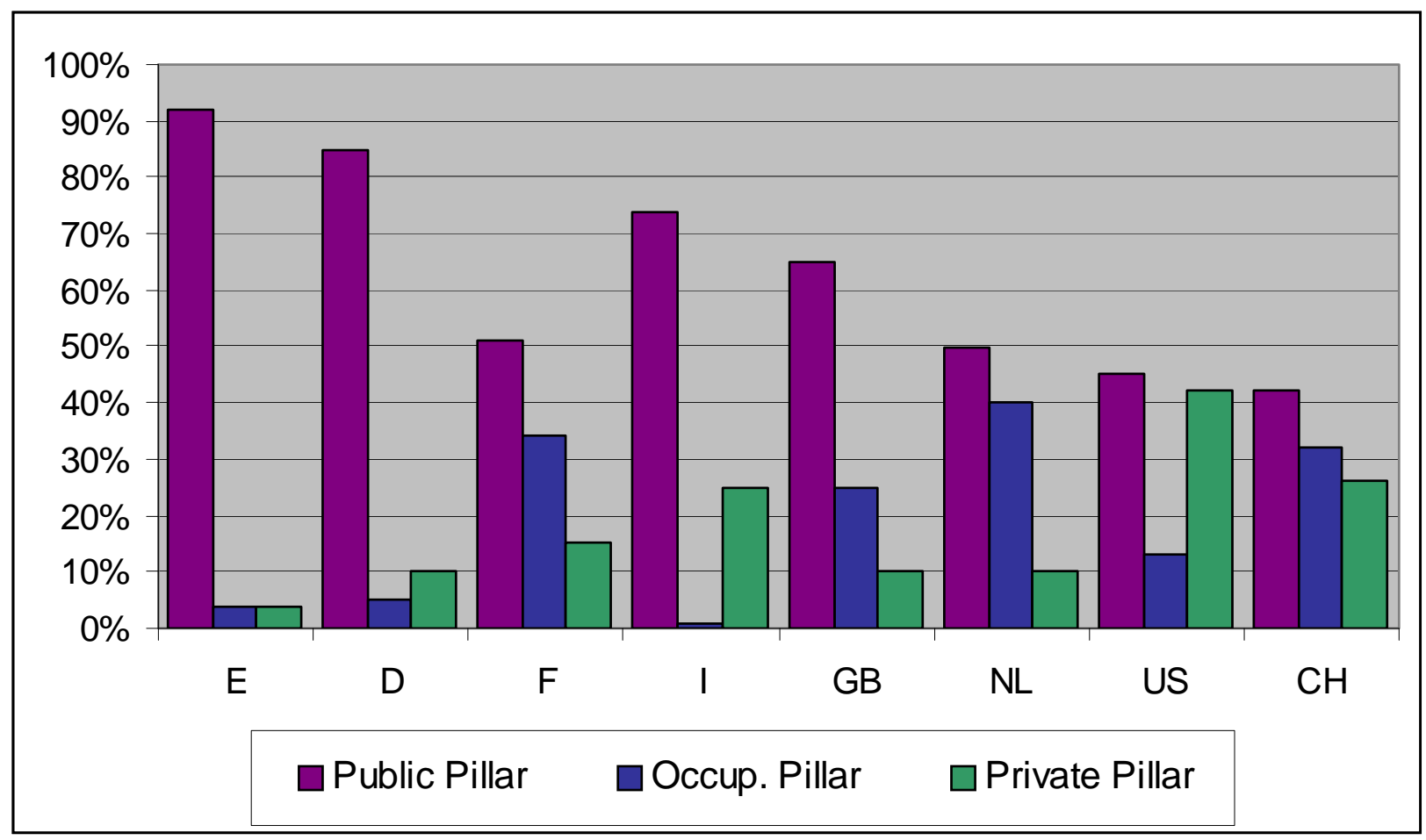

Source: Updated from Börsch-Supan and Miegel (2001) 


\section{Figure 3: Gross relative pension level}

(Average pension in percent of average earnings)

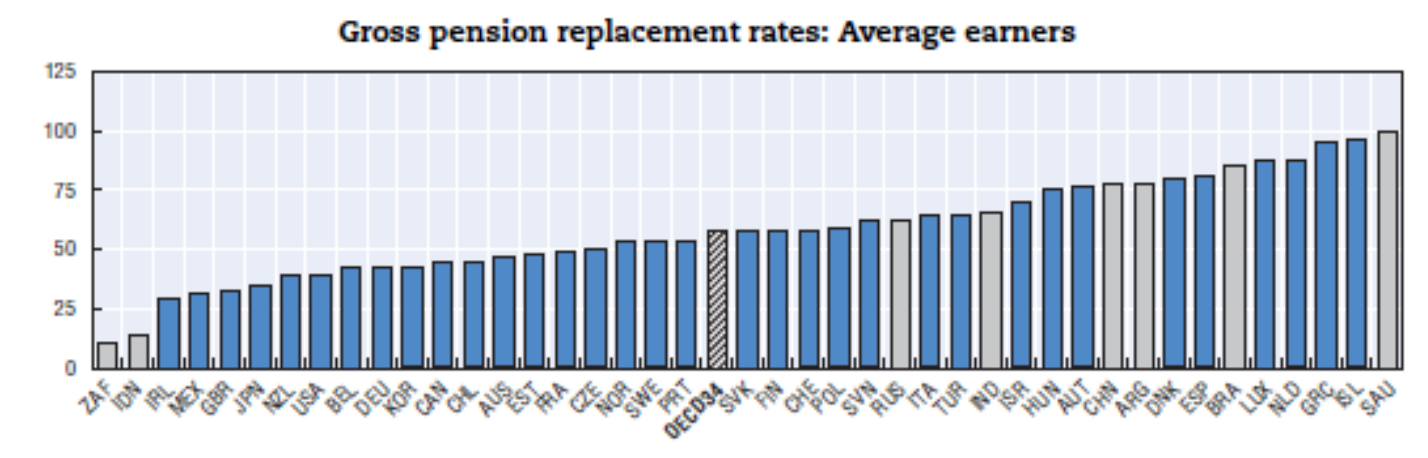

Source: OECD pension models.

StatLionk ace http//dx.doi.org/10.1787/888932370835

Source: OECD, Pensions at a Glance, 2011 
Figure 4: Statutory and effective retirement age

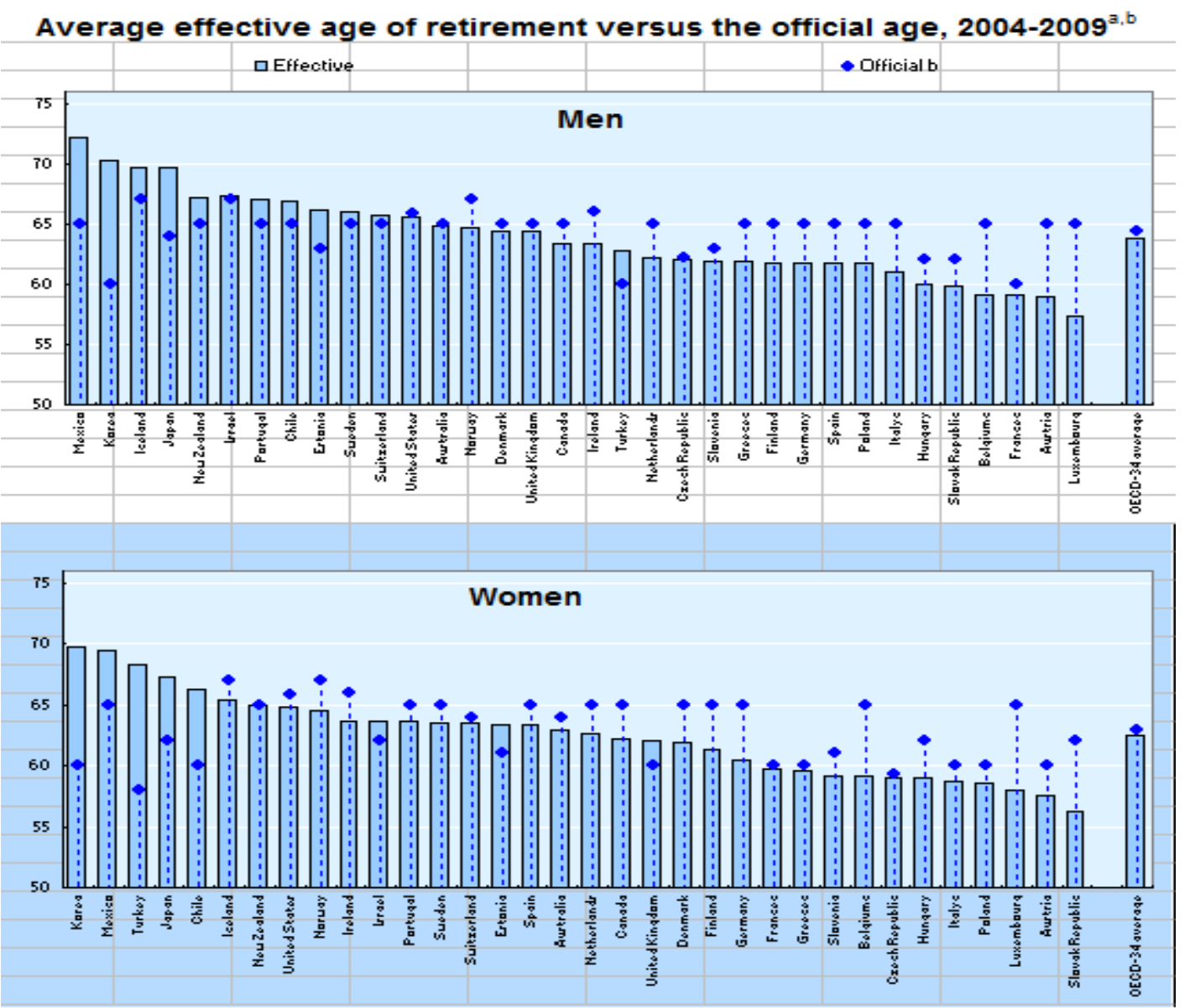

Source: OECD, Pensions at a Glance (2011) 
Figure 5: Pension Expenditures (Percent of GDP, 2011) by Old-Age Dependency (Percent)

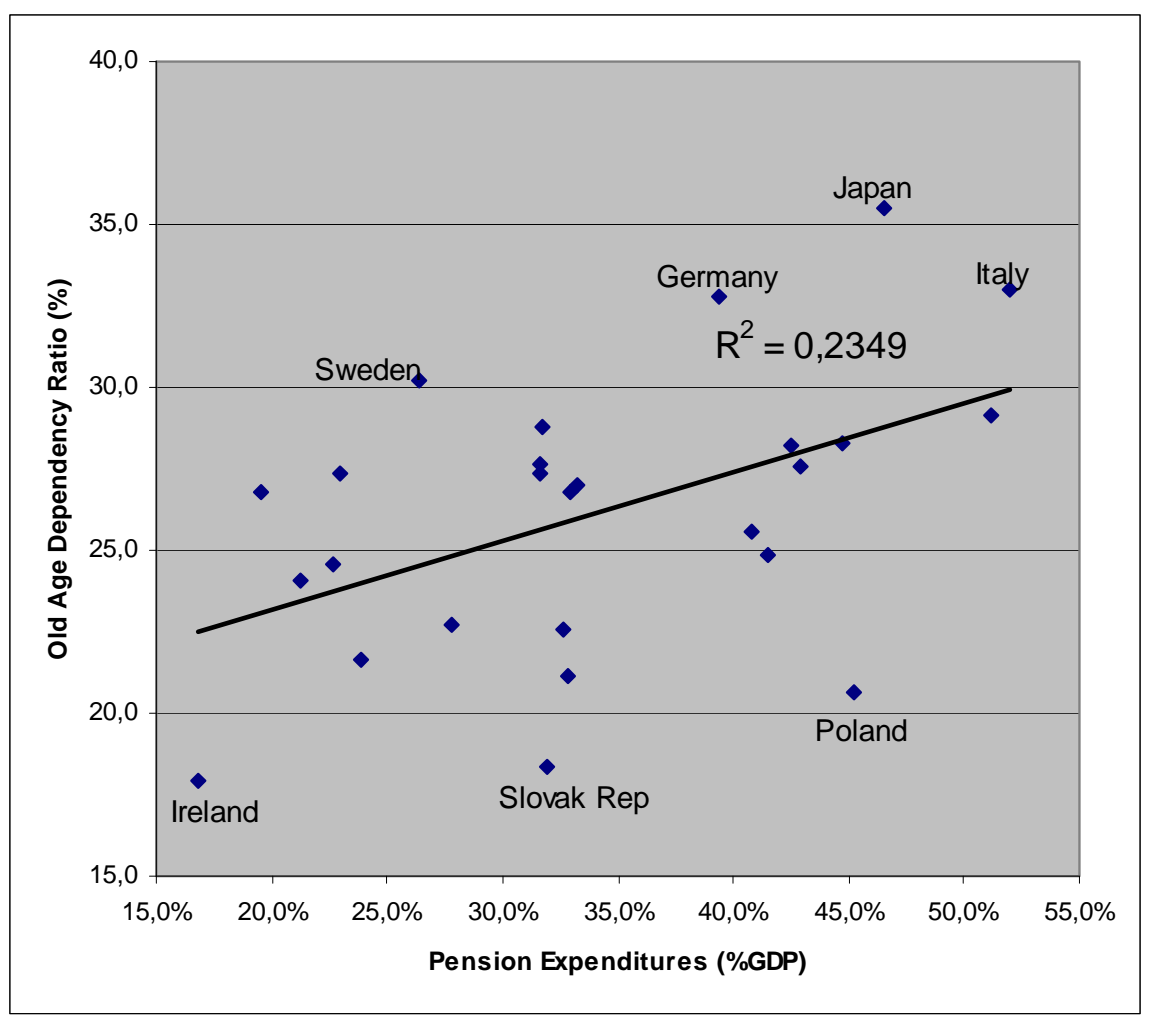

Source: OECD Social Expenditure database (SOCX, www.oecd.org/els/social/expenditure, November 2011). 
Figure 6: Change in Pension Expenditures (Percent, 2030 and 2050 versus 2010)

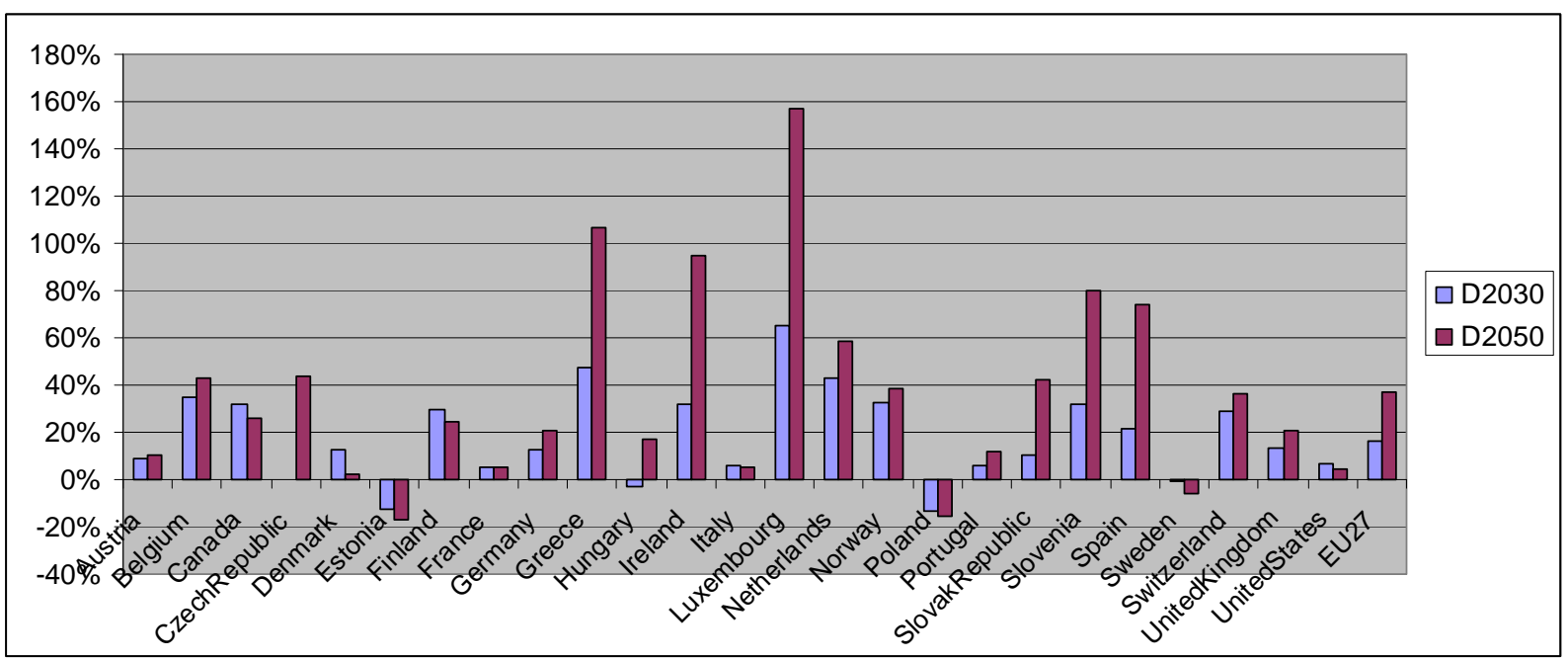

Source: EPC projections in EU, OECD elsewhere. OECD Social Expenditure database (SOCX, www.oecd.org/els/social/expenditure, November 2011). 


\section{Figure 7: The Old-Age Dependency Ratio in Europe and Selected Countries}

(Population 65+/population 20-64: 2010-2050)

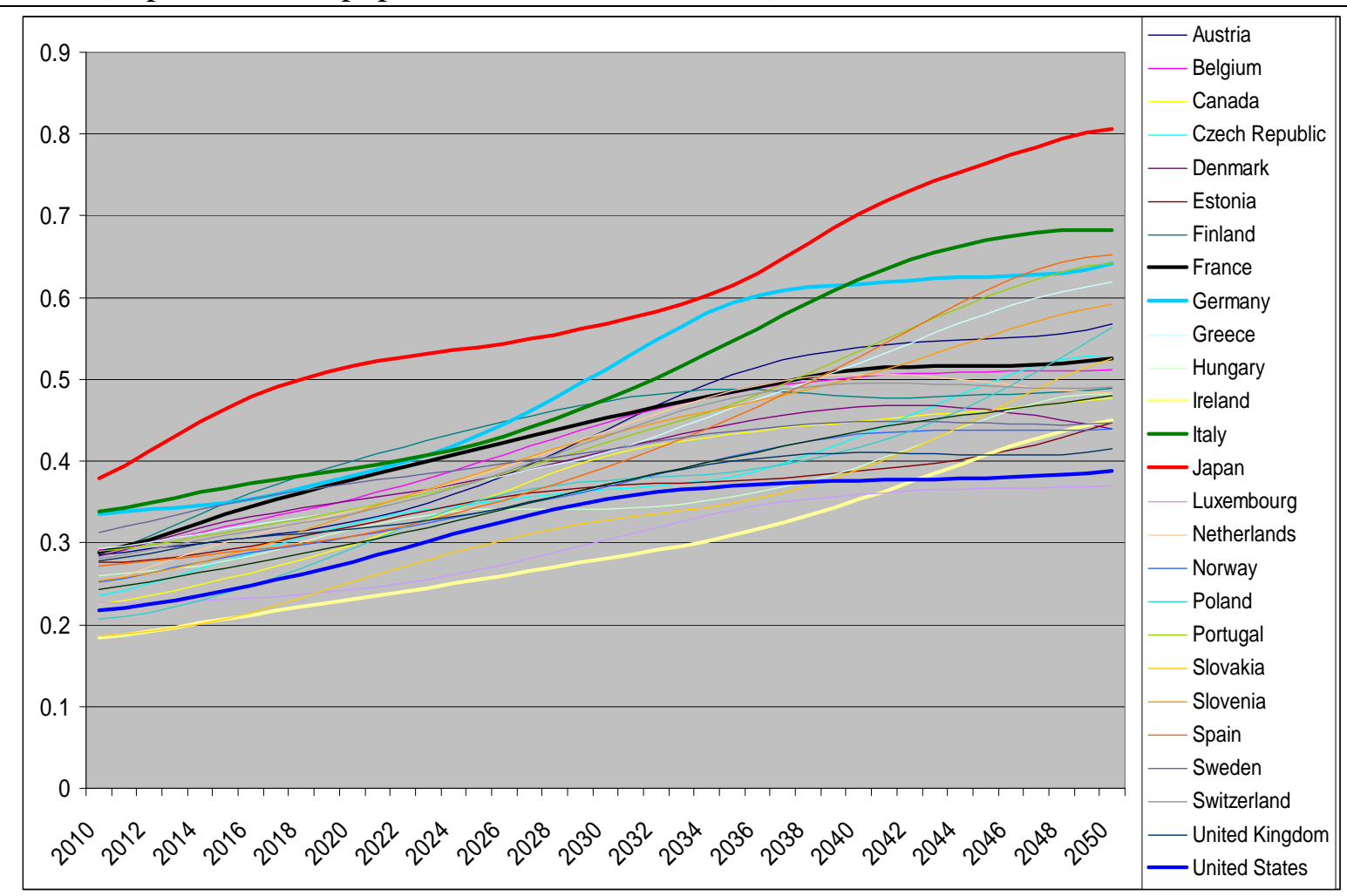

Source: EPC projections in EU, OECD elsewhere. OECD Social Expenditure database (SOCX, www.oecd.org/els/social/expenditure, November 2011). 


\section{Figure 8: Baby Boom to Baby Bust Transition in Europe}

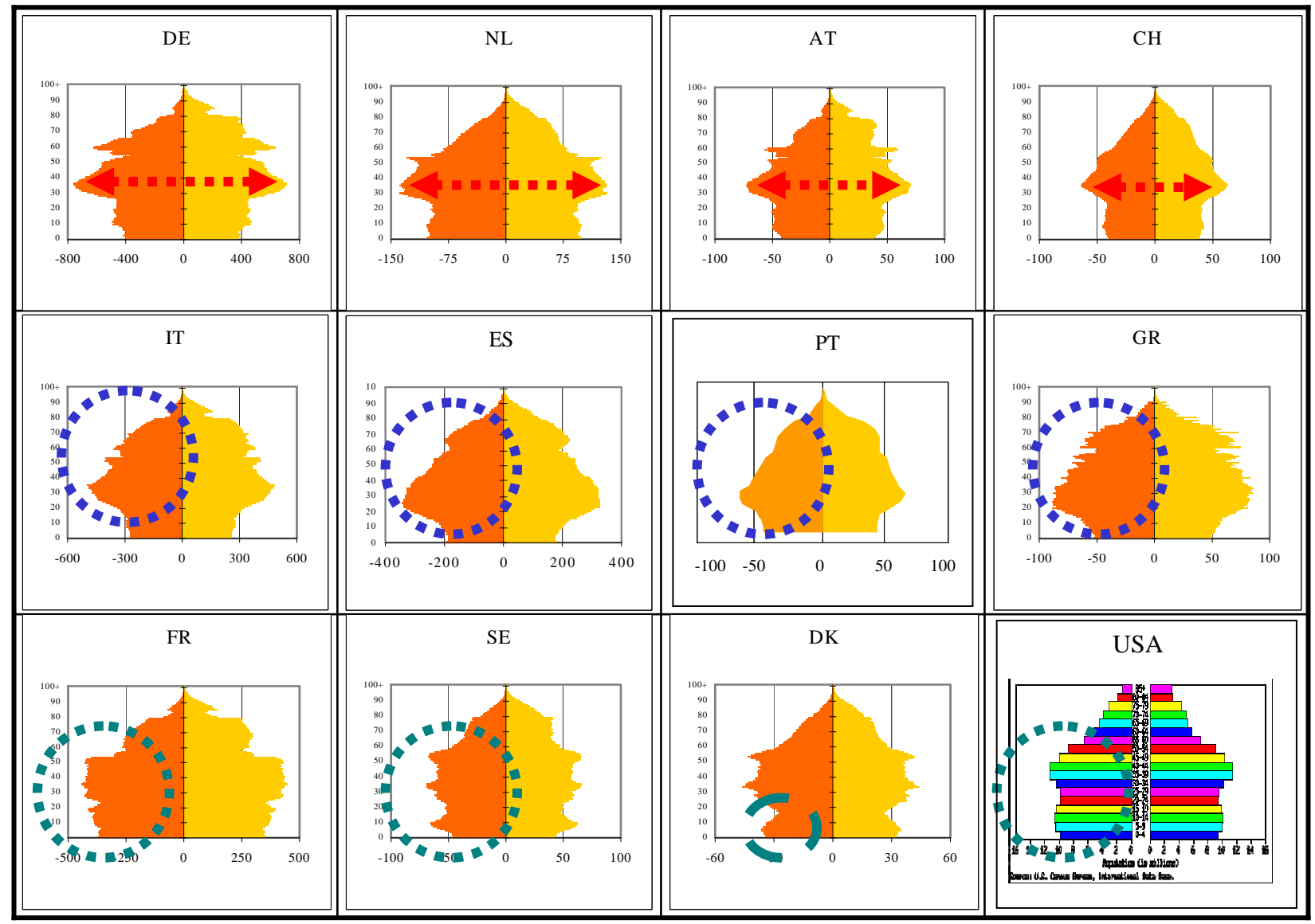

Source: Own depiction based on Eurostat and US Census IDB data 
Figure 9: Life Expectancy at Age 65, German Men and Women, 1970-2040

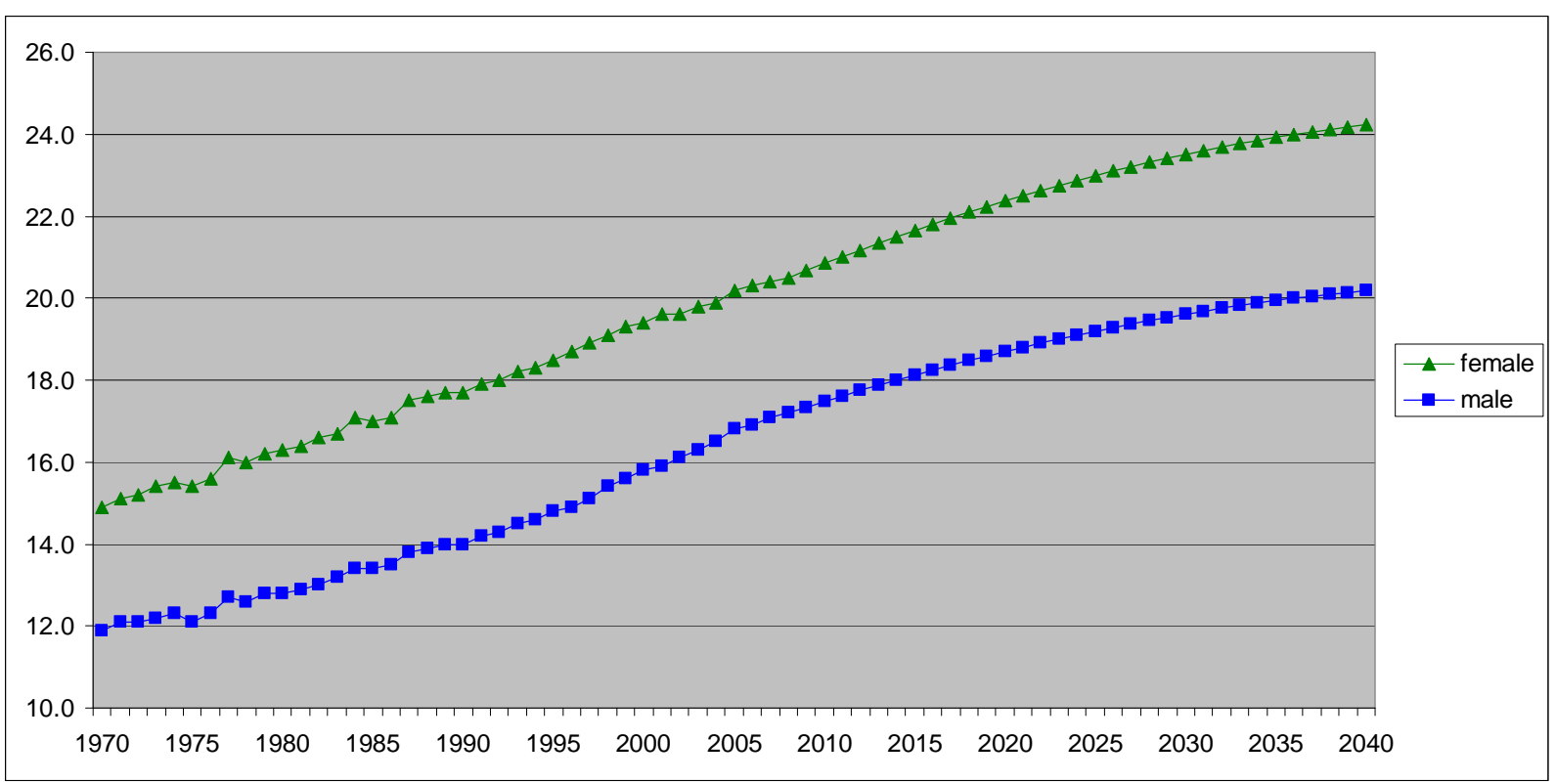

Source: 1970-2008: Statistisches Bundesamt; 2009-2040: MEA-Projection 
Figure 10: Composition of total hourly labor compensation in Europe (percent, Eurostat)

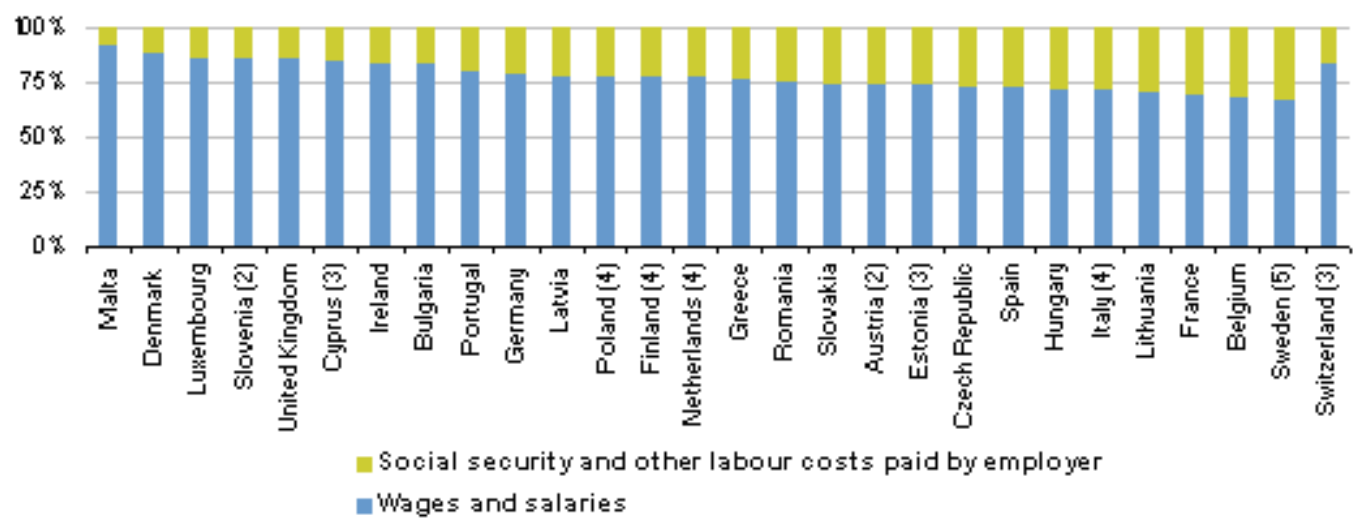

Source: Eurostat (on line data codes: lc_an_struc and lc_an_struc_r2) 
Figure 11: Tax force and early retirement

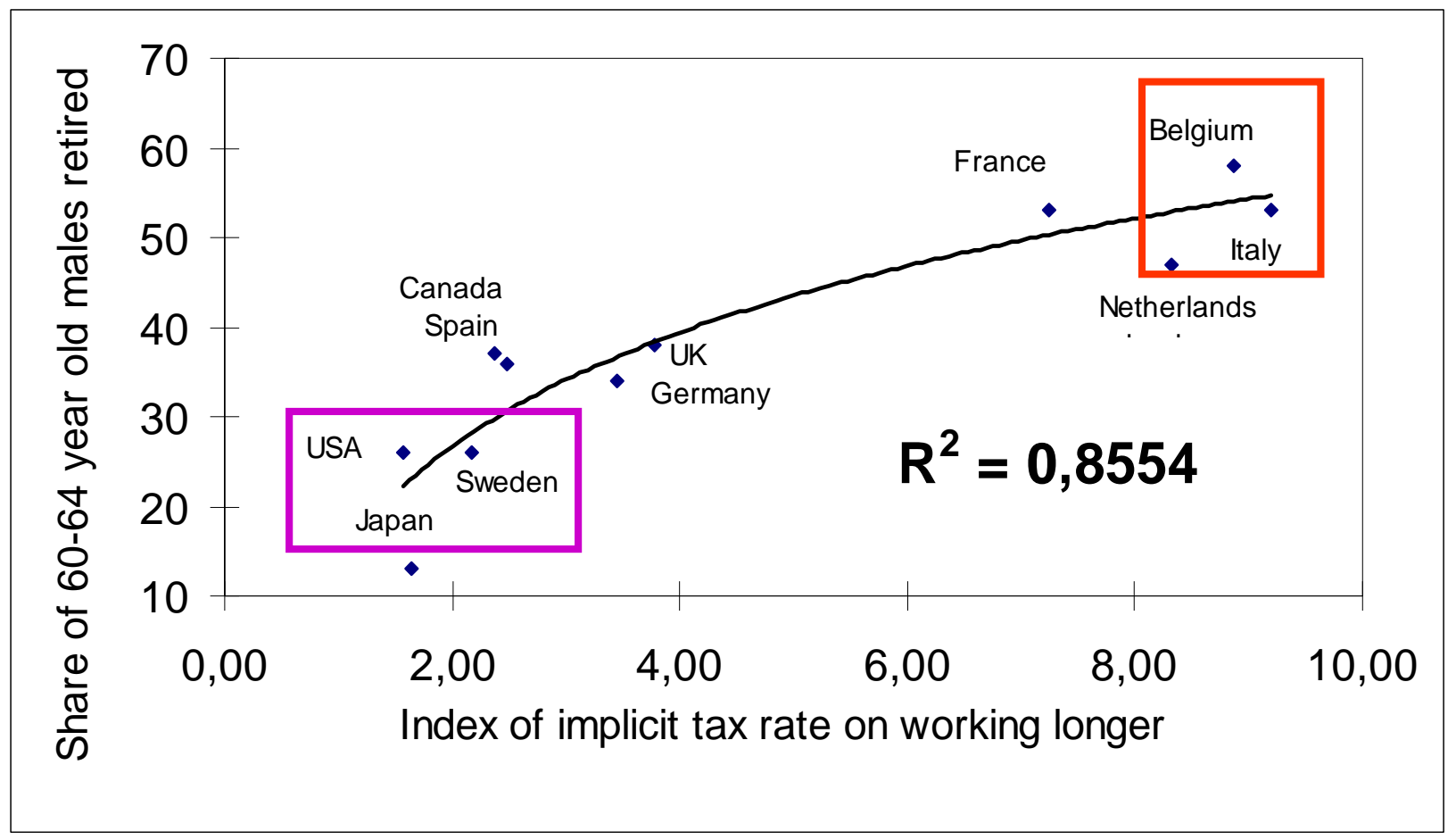

Source: Börsch-Supan (2000) adapted from Gruber and Wise (1999) 
Figure 12: Labor force participation among men aged 60-64, 1960-2008 (percent of male population 60 to 64)

\section{LFP trends for men 60 to 64}

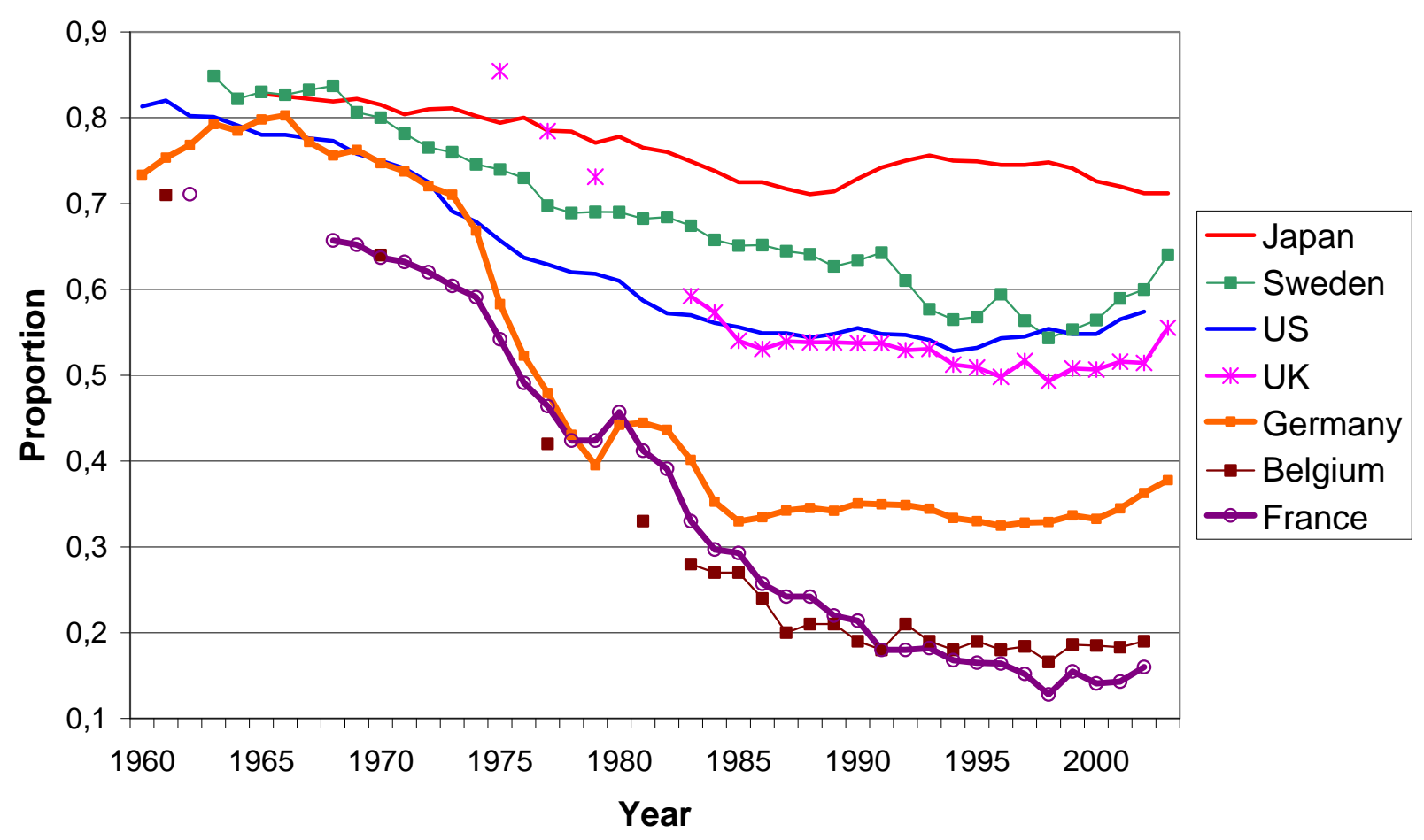

Source: Gruber and Wise (2010) 
Figure 13: Average Retirement Age in Germany, 1960-2008

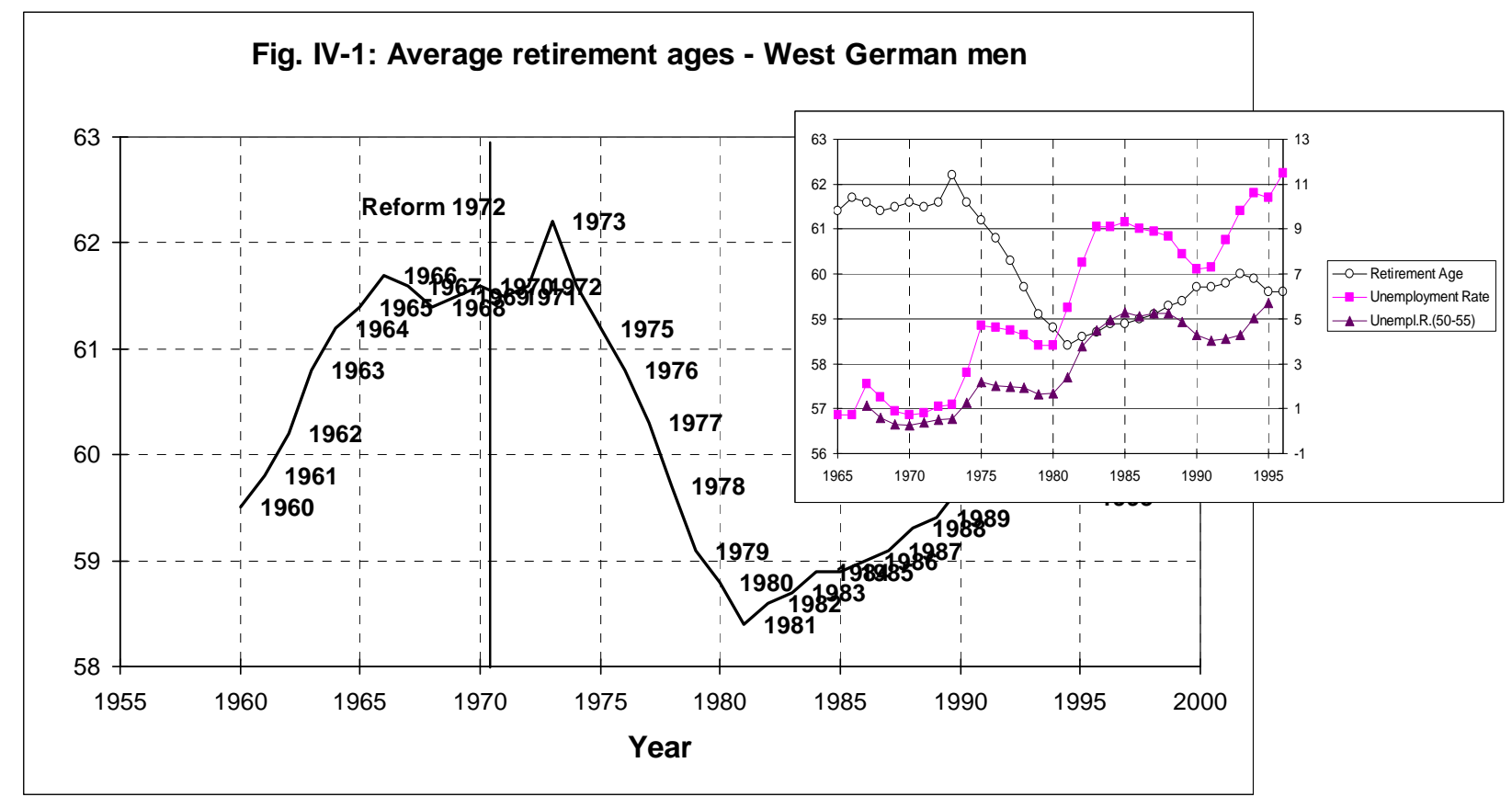

Source: Börsch-Supan and Schnabel (2010)

Get original and delete unemployment rates 
Figure 14: Old-Age Poverty Rates, 2010

(OECD, 2008)

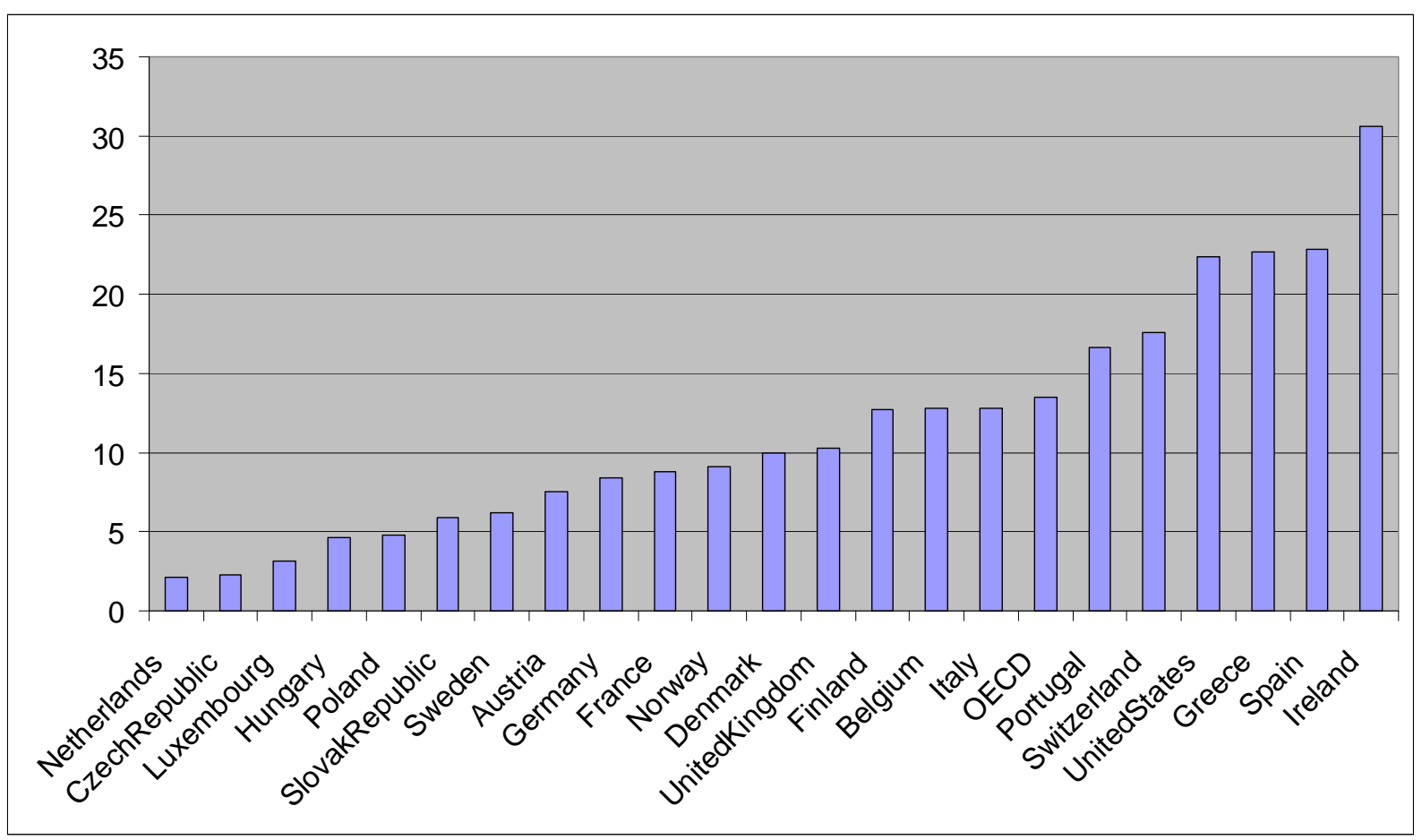

Source: OECD, Pensions at a Glance (2011) 


\section{Figure 15: The force of aging in terms of the rate of economic growth}

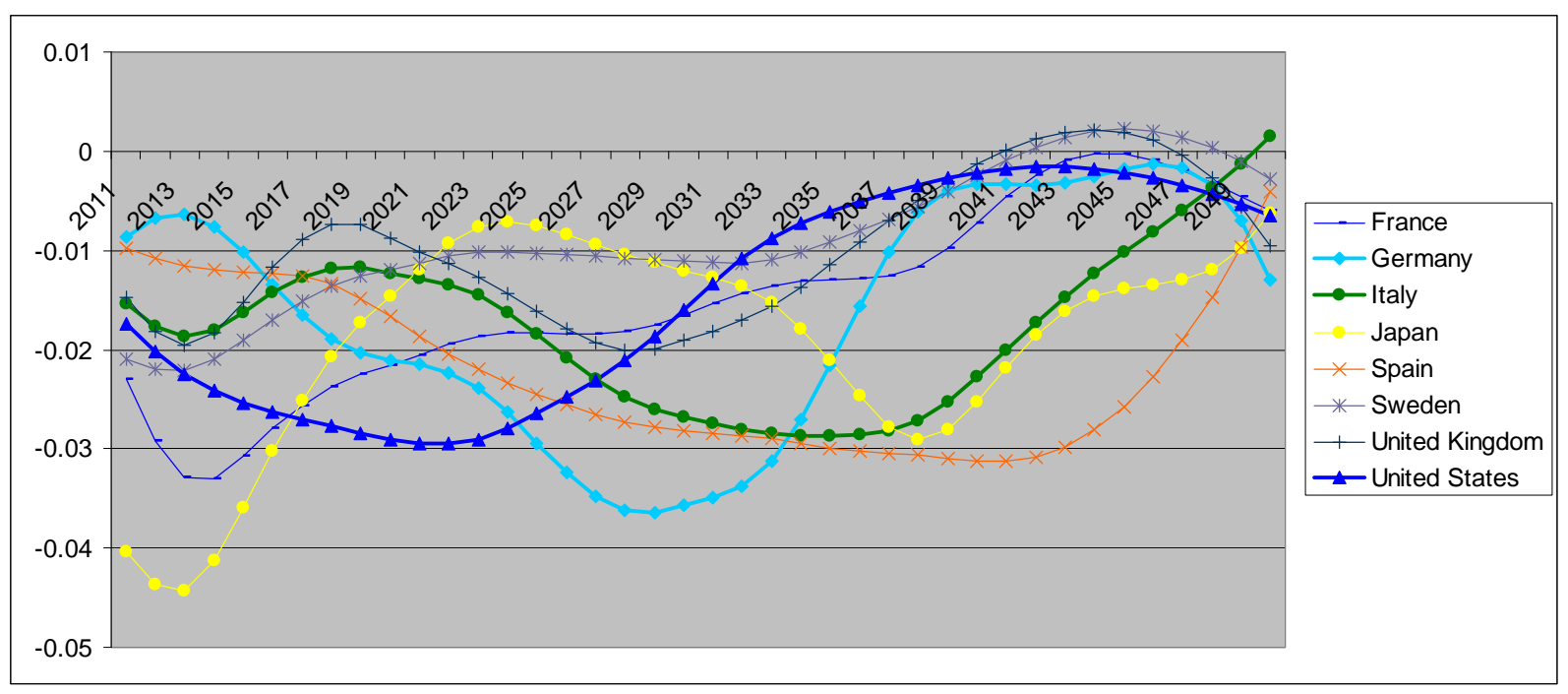

Source: Own calculations based on OECD Social Expenditure database (SOCX, www.oecd.org/els/social/expenditure, November 2011). 
Figure 16: Projected Retirement Age, Germany, 1997-2035

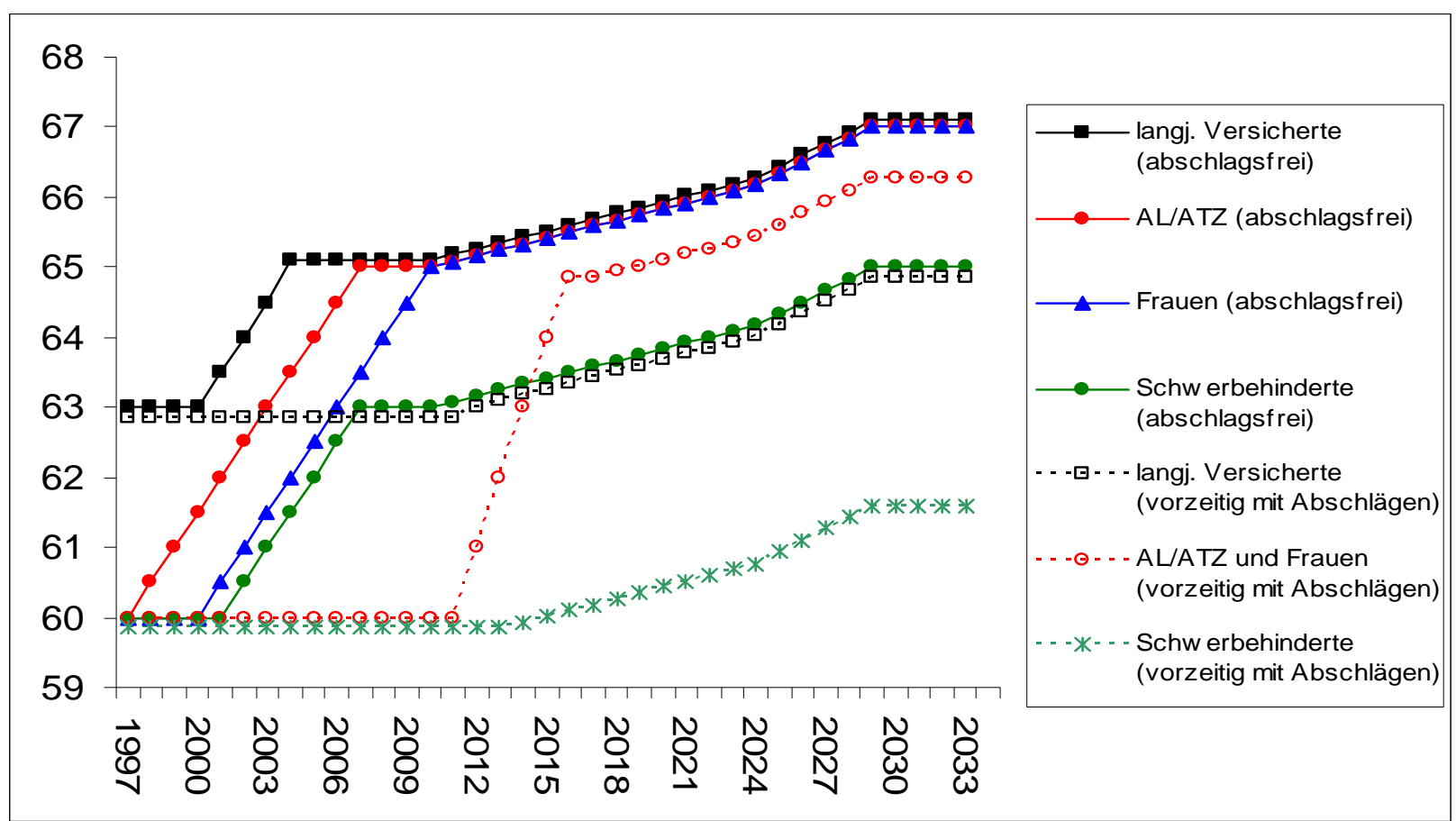

Source: Updated from Berkel and Börsch-Supan (2004). 
Figure 17: Projected Retirement Income Components, Germany, 2002-2040

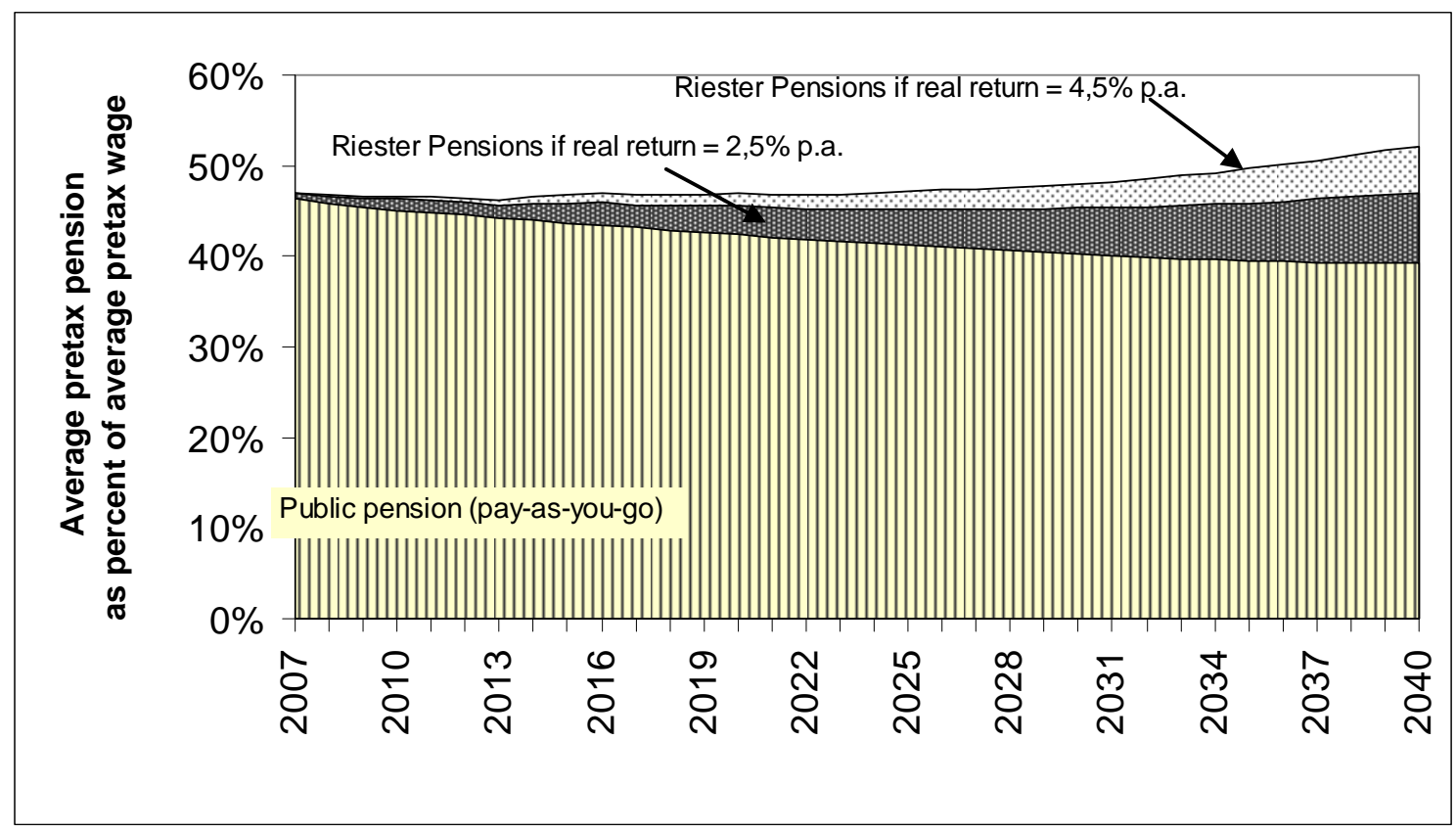

Source: Börsch-Supan, Bucher-Koenen, Reil-Held and Wilke (2008). 
Figure 18: Projected Public Pension Expenditures (\% GDP), 2007-2050

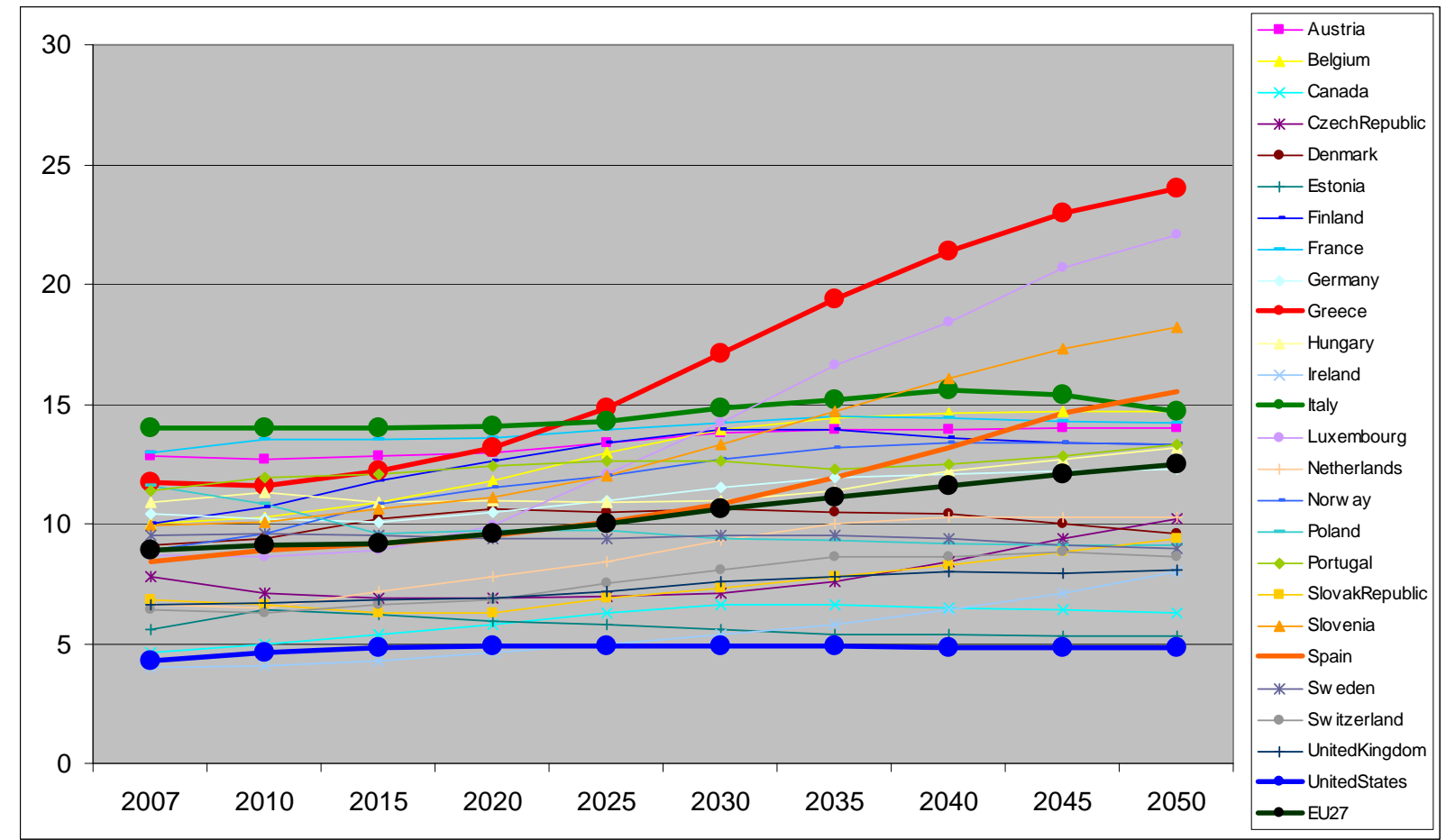

Source: EPC projections in EU, OECD elsewhere. OECD Social Expenditure database (SOCX, www.oecd.org/els/social/expenditure, November 2011). 
Figure 19: Projected implicit pension debt before and after recent reforms (\% GDP)

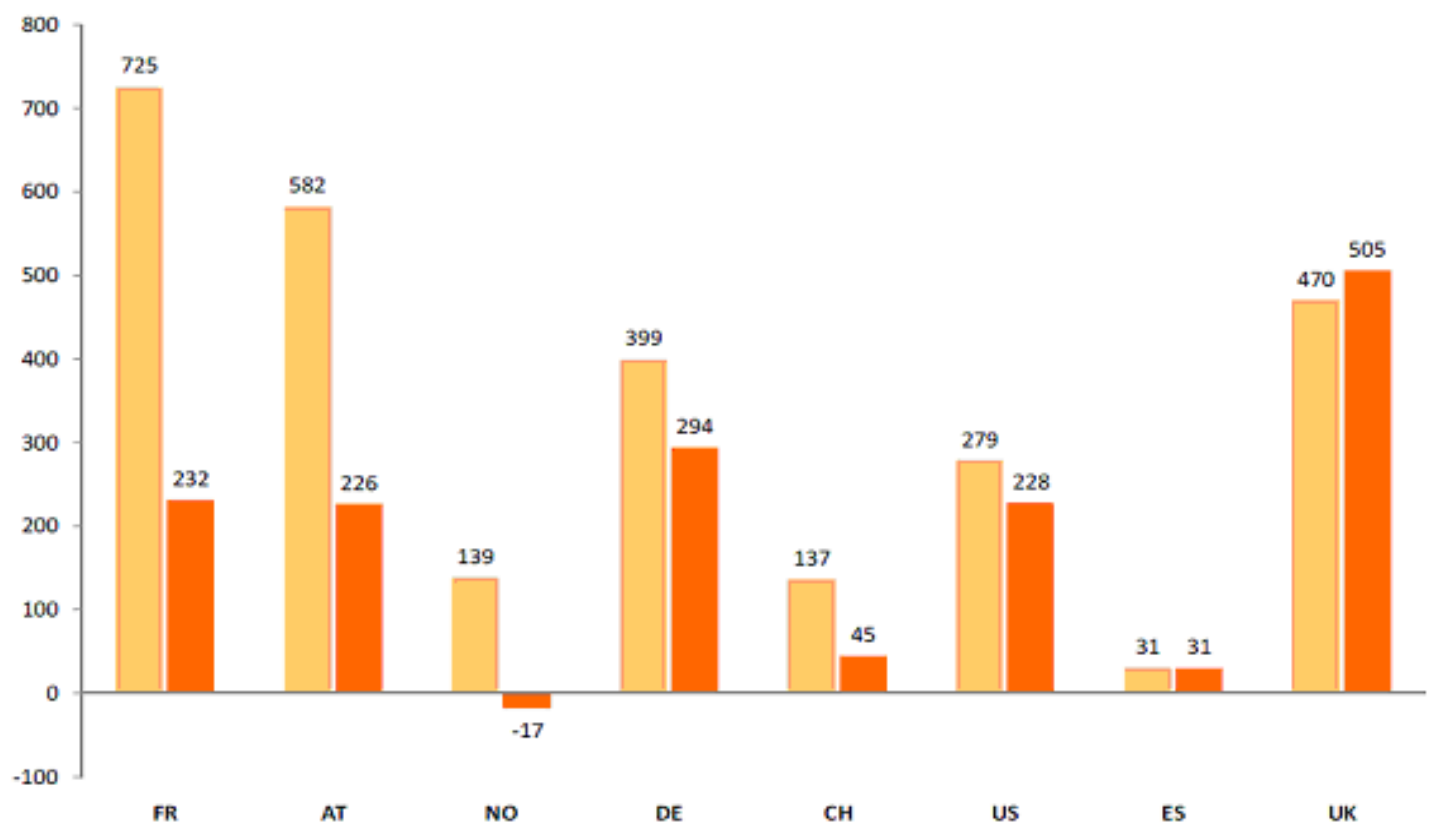

Source: Moog, Müller and Raffelhüschen (2010) 
Figure 20: Projected implicit pension debt before and after recent reforms (\% GDP)

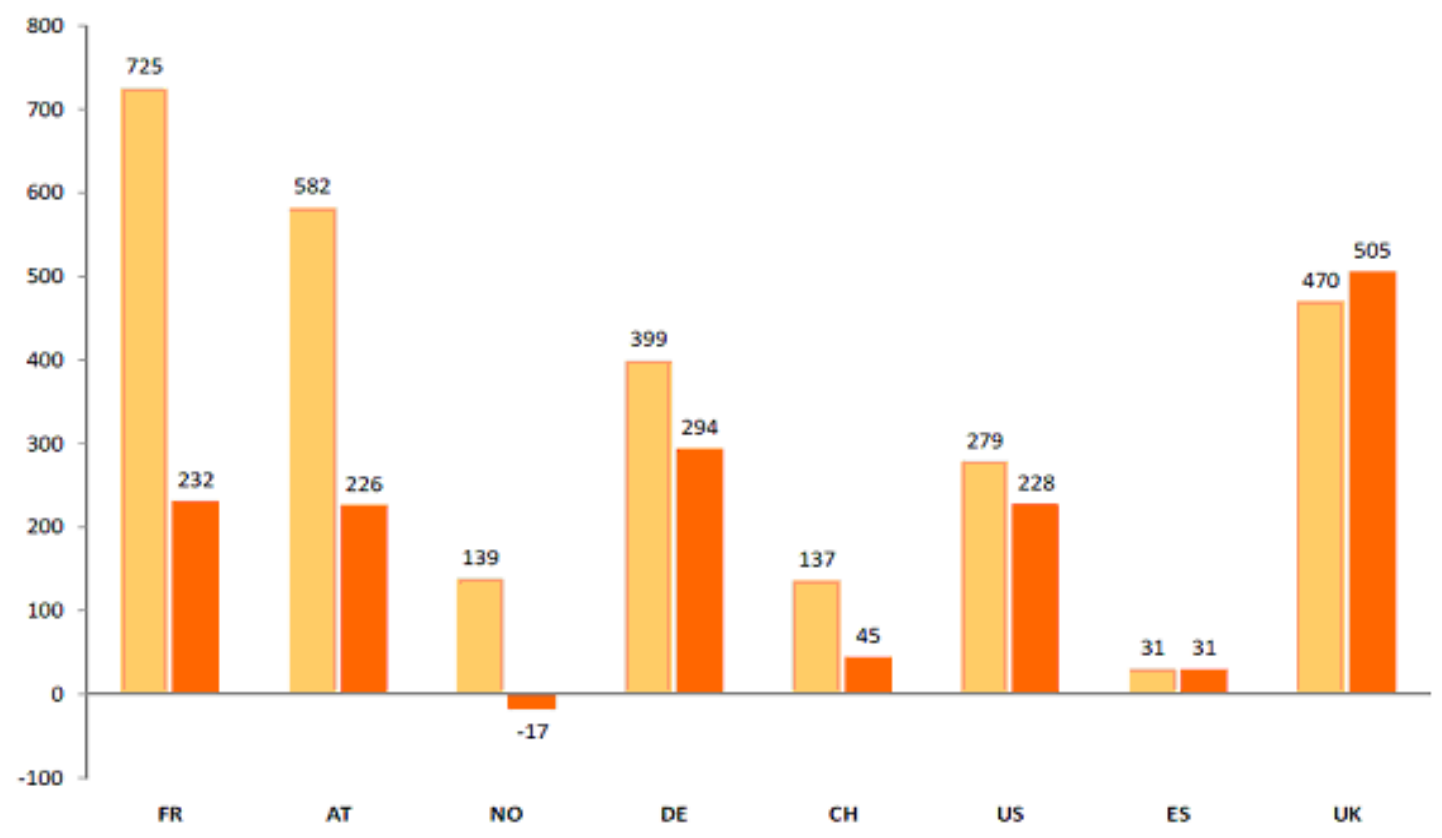

Source: Werding (2007) 


\section{Figure 21: Sustainability gap in Europe (\% GDP)}

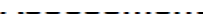

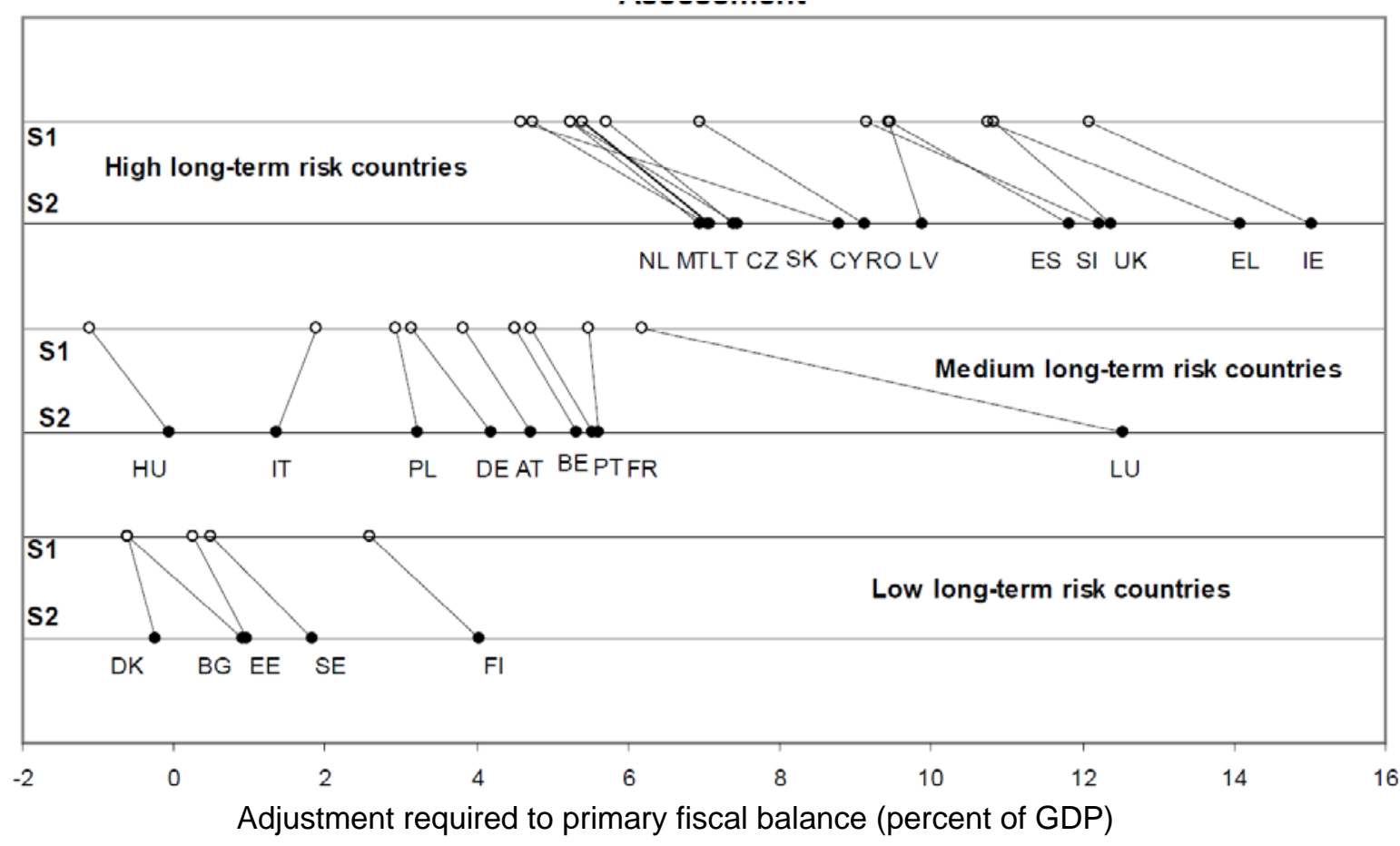

Source: European Commission (2010): Joint Report by the Economic Policy Committee, the Social Protection Committee and Commission services 
Table 1: Structure of Entitlement Programs, 2011

Percent of Total Entitlement Programs

\begin{tabular}{|c|c|c|c|c|}
\hline 2011 & pensions & health & working age & children/other \\
\hline Austria & $43,0 \%$ & $24,5 \%$ & $20,5 \%$ & $12,1 \%$ \\
\hline Belgium & $31,8 \%$ & $25,7 \%$ & $27,5 \%$ & $15,1 \%$ \\
\hline Canada & $23,9 \%$ & $44,1 \%$ & $14,5 \%$ & $17,5 \%$ \\
\hline Czech Repub & $32,7 \%$ & $29,2 \%$ & $23,1 \%$ & $15,1 \%$ \\
\hline Denmark & $19,6 \%$ & $22,3 \%$ & $26,8 \%$ & $31,3 \%$ \\
\hline Estonia & $31,7 \%$ & $22,1 \%$ & $30,4 \%$ & $15,8 \%$ \\
\hline Finland & $31,6 \%$ & $22,0 \%$ & $25,1 \%$ & $21,3 \%$ \\
\hline France & $42,5 \%$ & $25,0 \%$ & $16,6 \%$ & $15,9 \%$ \\
\hline Germany & $39,4 \%$ & $30,6 \%$ & $15,6 \%$ & $14,4 \%$ \\
\hline Greece & $51,1 \%$ & $25,8 \%$ & $10,0 \%$ & $13,1 \%$ \\
\hline Hungary & $40,8 \%$ & $22,8 \%$ & $23,6 \%$ & $12,8 \%$ \\
\hline Ireland & $16,8 \%$ & $27,0 \%$ & $36,8 \%$ & $19,3 \%$ \\
\hline Italy & $51,9 \%$ & $24,7 \%$ & $11,5 \%$ & $11,8 \%$ \\
\hline Japan & $46,5 \%$ & $33,5 \%$ & $8,5 \%$ & $11,5 \%$ \\
\hline Luxembourg & $27,8 \%$ & $27,7 \%$ & $28,1 \%$ & $16,4 \%$ \\
\hline Netherlands & $21,3 \%$ & $27,5 \%$ & $27,3 \%$ & $23,9 \%$ \\
\hline Norway & $22,6 \%$ & $25,4 \%$ & $26,4 \%$ & $25,6 \%$ \\
\hline Poland & $45,2 \%$ & $22,0 \%$ & $17,2 \%$ & $15,5 \%$ \\
\hline Portugal & $44,8 \%$ & $26,9 \%$ & $18,7 \%$ & $9,7 \%$ \\
\hline Slovak Repub & $31,9 \%$ & $30,7 \%$ & $23,7 \%$ & $13,7 \%$ \\
\hline Slovenia & $41,5 \%$ & $24,3 \%$ & $19,2 \%$ & $15,0 \%$ \\
\hline Spain & $33,0 \%$ & $23,8 \%$ & $25,5 \%$ & $17,8 \%$ \\
\hline Sweden & $26,4 \%$ & $24,4 \%$ & $20,8 \%$ & $28,5 \%$ \\
\hline Switzerland & $33,2 \%$ & $28,2 \%$ & $24,7 \%$ & $13,9 \%$ \\
\hline United Kingdo & $23,0 \%$ & $29,3 \%$ & $23,2 \%$ & $24,6 \%$ \\
\hline United States & $32,9 \%$ & $44,7 \%$ & $15,1 \%$ & $7,3 \%$ \\
\hline
\end{tabular}

Note: The countries with the two highest and two lowest values are marked in color.

Source: OECD Social Expenditure database (SOCX, www.oecd.org/els/social/expenditure, November 2011). 
Table 2: Structure of Pension Programs, 2010

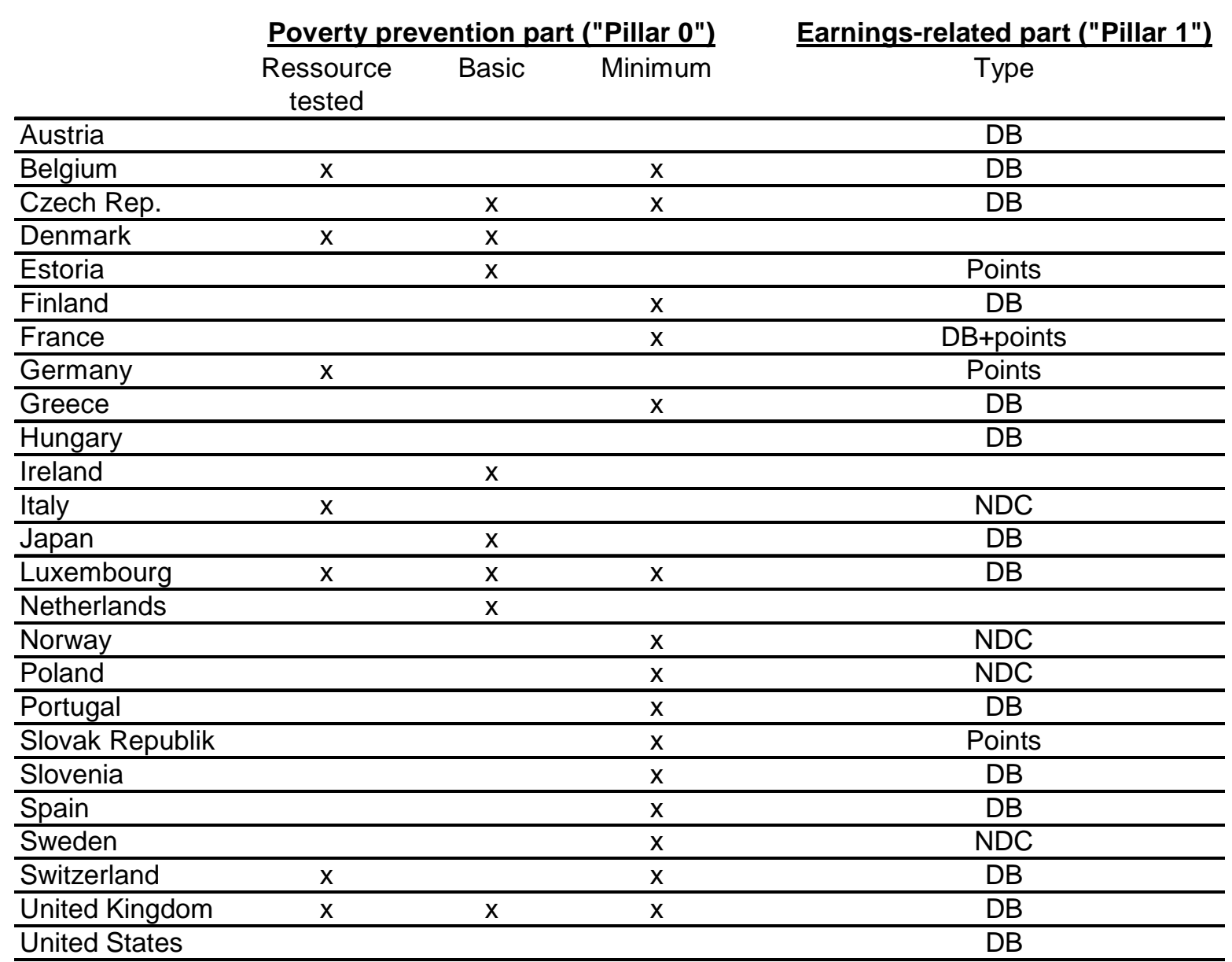

Notes: Resource-tested plans pay a higher benefit to poorer pensioners. The value of benefits depends on income from other sources and, in some countries, on assets.

Basic schemes pay flat benefits (in some countries, their value depends on years of work but not on past earnings. Additional retirement income does not change the entitlement.

Minimum pensions are resource-tested plans in which the value of entitlements takes account only of pension income but it is not affected by income from savings, etc. In some countries, benefits for workers with very low earnings are calculated as if the worker had earned at a higher level.

Defined-benefit (DB) plans: Retirement income depends on the number of years of contributions and individual earnings.

Point schemes: Workers earn pension points based on their earnings each year. At retirement, the sum of pension points is multiplied by a pension-point value to convert them into a regular pension payment.

Defined-contribution (DC) plans: contributions flow into an individual account. The accumulation of contributions and investment returns is converted into a pension-income stream at retirement.

Notional defined countribution (NDC) plans record contributions in an individual account and apply a rate of return to the balances. The accounts are "notional" in that the balances exist only on the books of the managing institution. At retirement, the accumulated notional capital is converted into a stream of pension payments using a formula based on life expectancy.

Source: Adapted from OECD, Pensions at a Glance, 2011 
Table 3: Synopsis of pension reform elements in Europe, 1980-2010

\begin{tabular}{|l|c|c|c|}
\hline & Retirement age & $\begin{array}{c}\text { Link of benefits to } \\
\text { contributions }\end{array}$ & Indexation \\
\hline Austria & women $\rightarrow 65$ & + & \\
\hline Germany & all $\rightarrow 67$ & (universal point sys) & Sustainability \\
\hline France & all $\rightarrow 62$ & Basis of point system & \\
\hline Italy & & NDC & NDC \\
\hline Spain & & & \\
\hline Greece & & Partially & \\
\hline Denmark & all $\rightarrow 67$ rev & NDC & \\
\hline Sweden & DI & point & life expectancy \\
\hline Norway & & scale factors & \\
\hline Finland & UI tunnel & & \\
\hline Netherlands & EEA, DI & & price $\rightarrow$ wage \\
\hline UK & all $\rightarrow 68$ & & \\
\hline US & all $\rightarrow 67$ & & \\
\hline
\end{tabular}


Table 4: Decomposition of Projected Changes in Pension Expenditure, 2005-2050 (gross public pension expenditures as percent of GDP)

\begin{tabular}{lccccccc} 
& $\begin{array}{c}\text { Level } \\
\mathbf{2 0 0 5}\end{array}$ & $\begin{array}{c}\text { Percent change } \\
\mathbf{2 0 0 5 - 2 0 5 0}\end{array}$ & $\begin{array}{c}\text { Dependency } \\
\text { ratio }\end{array}$ & $\begin{array}{c}\text { Employment } \\
\text { rate }\end{array}$ & $\begin{array}{c}\text { Take up } \\
\text { ratio }\end{array}$ & $\begin{array}{c}\text { Benefit } \\
\text { ratio }\end{array}$ & $\begin{array}{c}\text { Residual } \\
\text { (interaction) }\end{array}$ \\
\hline Austria & 13.2 & -1.0 & 11.3 & -1.3 & -5.8 & -4.3 & -0.8 \\
\hline Belgium & 10.4 & 5.1 & 7.7 & -1.5 & -0.4 & -0.6 & -0.1 \\
\hline Denmark & 9.5 & 3.2 & 7.2 & -0.4 & -2.8 & -0.5 & -0.3 \\
\hline Finland & 10.4 & 3.3 & 8.8 & -0.9 & -3.1 & -0.9 & -0.6 \\
\hline France & 12.9 & 2.0 & 9.7 & -0.9 & -1.9 & -3.5 & -0.5 \\
\hline Germany & 11.1 & 1.9 & 7.5 & -1.1 & -0.6 & -3.5 & -0.4 \\
\hline Ireland & 4.6 & 6.5 & 7.9 & -0.5 & -1.4 & 0.8 & -0.2 \\
\hline Italy & 14.3 & 0.4 & 11.5 & -2.0 & -3.2 & -5.3 & -0.7 \\
\hline Luxembourg & 10.0 & 7.4 & 7.2 & -4.4 & 2.5 & 2.1 & -0.0 \\
\hline Netherlands & 7.4 & 3.8 & 6.3 & -0.2 & -1.6 & -0.4 & -0.3 \\
\hline Portugal & 11.5 & 9.3 & 13.7 & -0.2 & -3.9 & -3.0 & -0.4 \\
\hline Spain & 8.7 & 7.0 & 12.4 & -1.8 & -2.3 & -0.8 & -0.4 \\
\hline Sweden & 10.4 & 0.9 & 4.8 & -0.6 & 0.2 & -2.8 & -0.2 \\
\hline United Kingdom & 6.7 & 1.9 & 4.7 & -0.1 & 0.0 & 0.0 & -2.6 \\
\hline Source: Caran
\end{tabular}

Source: Carone, Costello, Diez Guardia, Eckefeldt and Mourre (2008) 